Idaho National Engineering and Environmental Laboratory

INEEL/EXT-98-01120

November 1998

\title{
Haines - Scagway Submarine Cable Intertie Project, Haines to Scagway, Alaska
}

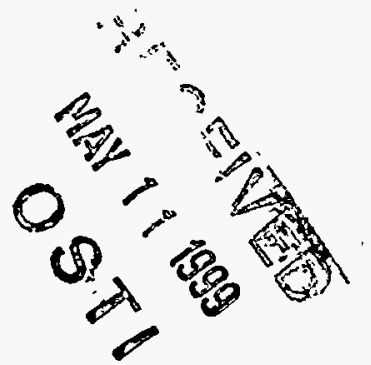

\section{Final Technical and Construction Report}

Glen Marin, Project Manager Alan See, President, Goat Lake Hydro, Inc. Alaska Power and Telephone Company

Bennie N. Rinehart, INEEL Consultant

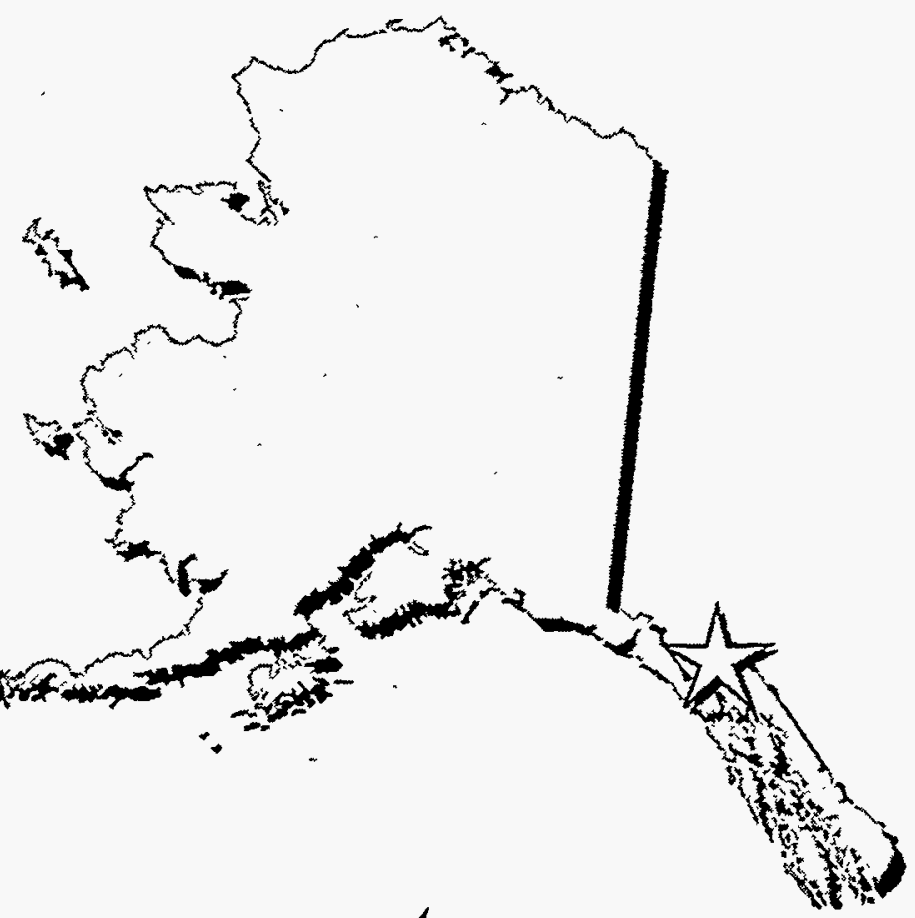




\title{
Haines - Skagway Submarine Cable Intertie Project, Haines to Skagway, Alaska
}

\section{Final Technical and Construction Report}

\author{
Prepared by \\ Glen Martin, Project Manager \\ Alan See, President, Goat Lake Hydro, Inc. \\ Alaska Power and Telephone Company \\ Bennie N. Rinehart, INEEL Consultant
}

Published November 1998

Idaho National Engineering and Environmental Laboratory Renewable Energy Products Department Lockheed Martin Idaho Technologies Company Idaho Falls, Idaho 83415

Prepared for the

U.S. Department of Energy

Assistant Secretary for Energy Efficiency and Renewable Energy

Under DOE Idaho Operations Office

Grant Agreement 2185053 


\section{DISCLAIMER}

Portions of this document may be illegible in electronic image products. Images are produced from the best available original document. 


\section{TABLE OF CONTENTS}

SECTION

$\underline{\text { PAGE }}$

1 - INTRODUCTION

1.1 - Location

1.2 - History

1.3 - Key Features

1.4 - Chronological History

1.5 - Power Purchase Agreement

2 - PROJECT FEASIBILITY AND PLANNING

2.1 - Introduction

2.2 - Initial Planning

2.3 - Permits

3 - PROJECT CONSTRUCTION

3.1 - Bathymetric Survey

3.2 - Placing the Splice Vaults

3.3 - Laying the Cable

4 - PROJECT COSTS

4.1 - Cost Estimates

5 - APPENDICES

Appendix A - Project Figures

Appendix B - Select Project Drawings

Appendix C - Project Photographs 


\section{SECTION 1}

\subsection{INTRODUCTION}

\subsection{LOCATION}

The submarine cable crossing from Skagway to Haines is located in Southeast Alaska at the head of Lynn Canal, in the Taiya and Chilkoot Inlet's, as in Figure 1. The USGS location is as follows: T28S, R59E, Sections 35, 34, 27, 23, 22, 15, 14; T29S, R59E, Sections 36, 25, 24; T29S, R6OE, Sections $31,30,19,18,7,6,5 ;$ T3OS, R59E, Sections 14, $13,12,11,10,1 ; T 30 S, R 60 E$, Sections 18, 7, 6 .

The project crossed from the Skagway City Limits into the Haines Borough. Both Skagway and Haines are terminuses of the Southeast Alaska Marine Highway System. This area is typified by rugged mountains, steep-walled valleys and glacial rivers, numerous glaciers, and ice-fields. Due to the high volume of freshwater and silt from the Taiya, Skagway, Chilkoot, Chilkat, and Katzehin Rivers and the deep, steep-sided nature of Taiya Inlet, the Inlet is not very productive for aquatic species. ${ }^{1}$

The Taiya Inlet consists of steep sides with mountains and glaciers in excess of 6,000 feet above sea level. The maximum water depth, along Taiya Inlet, is approximately 1,470 feet and it is in this deep channel that the cable was laid. At the Skagway end of Taiya inlet, the cable was laid along hard bottom and some alluvial fill. The cable rests on bedrock at the Otter Creek Project landing. The remainder of the cable rests on a sediment covered seabed, until the cable reaches Haines where it crosses a gravel beach.

\subsection{HISTORY}

With the completion of the Goat Lake Hydroelectric Project (near Skagway) in November, 1997 and the community of Haines generating power with diesel generators, the Applicant proposed to connect both communities to share the power generating capacity of the hydro project. The reasons for connecting Haines via a submarine cable are as follows:

- To provide an environmentally friendly source of power generation to meet the long term needs of the Haines area. As a result, this action will avoid the burning of over 850,000 gallons of diesel fuel per year.

- To reduce environmental and visual impacts by not installing an over-head transmission line from Skagway to Haines along Taiya Inlet.

\footnotetext{
'Skagway Coastal Management Program, Prepared by the City of Skagway, June 1, 1994.
} 
- To reduce the cost to consumers that are associated with the installation of an over-head transmission line.

- To provide stable rates for consumers. A decrease in the real cost of power (as adjusted for inflation) by maintaining stable rates in nominal dollars. The use of tax exempt bonds, thereby lowering the borrowing costs by almost $2 \%$, will assist in maintaining stable, low cost rates.

- This project will further administration and legislative objectives of increased rural self-reliance, long term economic growth, joint local/state participation in infrastructure development, regionalization of rural energy systems and increased use of renewable resources.

\subsection{KEY FEATURES}

As Constructed in 1998

Type of Project

Type of Cable

Length

Maximum Depth

Number of Splice Vaults

Capacity
Laying of Submarine Cable

$35 \mathrm{kV}$, 3-Phase

Approximately 15 Miles

Approximately 1500 feet

3

Conservatively, $15 \mathrm{MW}$ continuous (at rated voltage)

\subsection{CHRONOLOGICAL HISTORY}

1. $1995-$

2. September 1996 - After sending Pirelli-Jacobson maps and information from Harza Engineering Intertie Study, they submitted updated Proposal that included increases in costs and time frame.

3. November 1996 - Requested and received permitting requirements and application from DNR. 
4. January 1997

- Met with Bryan Jacobson, Pirelli-Jacobson, to discuss their proposal, installation details, final cable design, and schedule.

- Survey Agreement signed. Will do survey when weather permits.

5. February 1997

- Received additional technical and commercial information and clarification from Pirelli-Jacobson.

- Signed Professional Service Agreement with RW Beck For Upper Lynn Canal Regional Power System Planning Review.

6. April 1997

- Interoffice Memo from Vern/Skagway: Review of Underwater Survey and inspection of Kasidaya Creek and Landfall area.

7. June 1997

- Notice to all participating agencies that the Submarine Cable Project is feasible.

8. July 1997

-Kevin (Craig) Keener, CRA, (sub-contractor for PirelliJacobson) notified Pirelli of GPS Positioning and Temporary Survey Points. There are no hazards of concern along the survey route.

- Applied to U.S. Army Corps of Engineers for a NationWide Permit.

-Request for Cost Estimate from Paul Gailey, Ph.D., Oak Ridge National Laboratory for Developing a Report on Submarine Cable Electro-Magnetic Fields.

-EMF Calculations received from Pirelli-Jacobson Re: the radiation effects of the submarine cable.

9. August 1997

- Issued Nationwide Permit \#D-970592 from Army Corps of Engineers.

10. September 1997

- Confirmed with FERC that the Submarine Cable Project is not part of Otter Creek Hydroelectric Project - more in relation to Goat Lake Hydroelectric, if any.

- After communicating with ADF\&G, notified PirelliJacobson of commercial fisheries schedules in July and that we must schedule around those openings.

- Applied to DGC for ACMP Determination.

- Applied to DNR for R/W/E Land Use Permit.

- Applied to USFS for Special Use Permit for Cable Splice Vaults.

- House of Representatives make appropriations for Upper 
Lynn Canal Regional Electric Project.

11. October 1997

- Congress passes FY98 legislation containing $\$ 1$ million in grant funding for Skagway-Haines submarine cable.

- President Clinton signed into law the FY98 Energy and Water Development Bill containing the grant funding.

- Notified AIDEA of proposed installation - Haines Intertie.

- Received permission from the White Pass \& Yukon RailRoad to place equipment.

- Cable Installation Agreement signed with PirelliJacobson.

12. November 1997 - Discussion with DGC, ADF\&G, DEC, and USFS re: revegetation, trenching, and erosion control methods.

- Issued ACMP Final Consistency Determination by DGC.

13. December 1997 -Informed DNR of Classification of Submerged Lands Maps showing Taiya Inlet as designated for submarine cable use.

- Sent DNR $\$ 3,200$ for fees to process right-of-way (ROW) and classification of submerged lands.

14. January 1998 -USFS issued Request for Comments to Interested Parties, re: Proposal Cable Splice Vault on National Forest System Land at Kasidaya Creek.

15. February 1998 - Sent revised cable installation schedule to all agencies.

16. March 1998 -DNR public notice for Application for Right-of-Way Permit \#ADL 106422.

17. April 1998 -Updated schedule received from Pirelli-Jacobson.

- \#ADL 106422.

- Updated schedule sent to DNR.

- City of Skagway notified DNR that they have no objection to the proposed project.

- USFS sent Decision Memorandum authorizing the cable splice vault project - Special Use Permit will follow.

- Received Final Finding \& Decision from DNR Right-of-Way Permit \#ADL106422.

18. May 1998

- Bennie Rinehart - DOE, reviews plans for laying the cable.

- Received draft Special Use Permit from USFS.

- Bill for Collection for $\$ 150$ from USFS for the Special Use Permit \#4306-03. 
19. June 1998 - Cable ship Sea Beach arrived in Seattle June $23^{\text {rd }}$.

- Received Final Special Use Permit \#4306-03.

- Sent DNR \$6,000 for Right-of-Way Permit, \$2,000

for the Bond along with signed permit.

- Received Right-of-Way/Early Entry Permit

\#ADL106422 from DNR (effective 6/1/98 to 5/31/99).

- Cable ship Sea Beach arrived in Southampton, England May 7th.

- Loading of Cable commenced on May 8th and departed on May 10th.

-DNR sent Instructions to Perform an As-Built Survey on State Land.

- Cable ship Sea Beach arrived in Skagway June $27^{\text {th }}$.

- Bennie Rinehart - DOE, observes the installation of the cable.

20. July $1998 \quad-$ Cable installation completed July $3^{\text {rd }}$.

- Certification of Completion of Activity sent to U.S. Army Corps of Engineers July $14^{\text {th }}$.

- Informed USFS of signage requirements.

- Pirelli-Jacobson sent test results performed on two sections of cable - Delivered spare cable and "As-Laid" drawings under separate cover.

21. August 1998

- Amendment to USFS Special Use Permit FS-2700-23 authorizing AP\&T to place warning signs.

22. September 1998 - Final "As-Laid" drawings sent to NOAA, NIMA, and U.S. Coast Guard-Juneau.

- Sent "As-Laid" drawings to Horan-Korak, Sitka, Alaska for survey of R/W/E.

\subsection{PROJECT FEASIBILITY AND PLANNING}

\subsection{INTRODUCTION}

The Haines to Skagway submarine cable project is located in Taiya Inlet, at the north end of Lynn Canal, in Southeast Alaska. The cable is approximately 15 miles long, with three landings and splice vaults. In Figure 2 , the cable route and landfalls are shown. The cable is $35 \mathrm{kV}, 3-$ Phase, and armored. The diagram in Figure 3 shows a cross section of the cable. The cable interconnects the Goat Lake Hydro Project near Skagway with the 
community of Haines. Both communities are now on $100 \%$ hydroelectric power.

The Haines to Skagway submarine cable is the result of AP\&T's goal of an alternative, economic, and environmentally friendly energy source for the communities served and to eliminate the use of diesel fuel as the primary source of energy. Diesel units will continue to be used as a backup system.

\subsection{INITIAL PLANNING}

Once the Federal Energy Regulatory Commission (FERC) issued the license for the Goat Lake Hydroelectric Project the go-ahead was given to investigate the interconnection of Haines with Skagway to provide the customers of Haines with the excess hydro power the Goat Lake Project would generate. Despite the fact that Haines Light and Power (a subsidiary of AP\&T) has a FERC preliminary permit to investigate the construction of a hydroelectric project, it was determined that the submarine cable would be more cost effective. With the Otter Creek Hydroelectric Project proposed 3 miles south of Skagway on Taiya Inlet, it would be a simple solution to plan for an eventual interconnection to the submarine cable via a splice vault and still be more economical than constructing Haines Light and Power's proposed hydro project.

The submarine cable plan called for a cable about 15 miles long, operated at 35 kilovolts, at 3-phase, alternating current. There would be three landfalls, one each at the ends and one at the Otter Creek Project site, about 3 miles south of Skagway, as shown in Figure 4.

The submarine cable would leave Skagway from the rock jetty on the south side of the Skagway River, where the ore terminal is located, as shown in Figure 5. The cable would descend into the Taiya Inlet and proceed along a

relatively smooth seabed. The cable would ascend to the Otter Creek Project site on the east side of Taiya Inlet to connect with a splice-vault, as shown in Figure 6. The splice-vault is for tying into a future hydro project presently under a FERC preliminary permit No. 11588. The cable will then descend from the splice-vault back into Taiya Inlet and proceed to Haines. The slope at the Haines end of the cable will be approximately $45^{\circ}$. The cable will landfall along the south side of Lutak Inlet, tying into the present transmission system, as shown in Figure 7.

The proposed submarine cable was expected to be laid in July, 1998 using a single ship to lay approximately 87,000 feet of cable in one pass along Taiya Inlet. Depending upon the weather, it was expected to take approximately 1 week to lay the cable. 
It was proposed that the submarine cable would leave Skagway from municipal/private land, cross into DNR tide lands and then into DNR submerged lands, NE $1 / 4, N W 1 / 4$, Section 14 . The cable continues through DNR submerged lands until it ascends to the Otter Creek Project site where it crosses DNR tide lands and enters into USFS managed lands (Tongass National Forest) to the cable splice-vault, W $1 / 2, N W 1 / 4$, Section 35 . After the cable leaves the splice-vault, it again passes through DNR tide lands and DNR submerged lands until the cable lands at Lutak Inlet, near Haines, SE $1 / 4$, SW $1 / 4$, Section 10, mile 4.4 of the Lutak Highway. At Lutak Inlet, the cable again crosses DNR tide lands and then onto the DOT right-of-way to interconnect with our present transmission system.

Trenching for the cable was proposed at both ends (Skagway and Haines) and at the Otter Creek Project landing, to protect the cable from anchors, fishing, and forces of nature. The cable would not cross any streams or any significant aquatic beds of harvestable foods. The cable would not pose any significant threat to the environment, nor harm aquatic life or pose a threat or hindrance to navigation within the Taiya Inlet or Chilkoot Inlet.

Trenching for the cable landings would not be longer than 200 feet. In Figure 8 the splice vault and buried portion of the cable landing is shown as it was proposed. The Applicant proposed to use a small excavator and backhoe to trench for the cable. The cable would be protected in an HDPE pipe from below the minimum low tide elevation to above the mean high tide elevation. The cable would then have a steel sleeve to protect the cable while crossing land above high tide to the splice vault. Trenching would take place during low tides for the area. Excavated material would be backfilled over the cable and its protective conduits.

After seeking qualified firms to supply and lay a submarine cable, Pirelli/Jacobson, Inc. of Seattle, Washington was hired to construct this 3phase cable which would include a fiber-optic cable. A cable purchase and installation agreement was signed with Pirelli/Jacobson, Inc. on March 26, 1997. The price breakdown of the submarine cable is as follows:

- Purchase price for cable

- Transportation of cable

- Cable installation

- Kasidaya Creek Landing (Otter Creek Project)
$\$ 3,000,000$

$\$ 600,000$

$\$ 1,550,000$

$\$ 110,000$

Pirelli/Jacobson, Inc. manufactures parts of the cable in England and Italy and completes the manufacture of the cable in England. Photographs of the manufacturing of the cable are shown in the Appendix B - Project

Photographs. The cable was then stored in England until AP\&T could expect 
to finished the installation of the splice vaults and when a special ship was available for transporting the cable.

Prior to laying the cable, the sea floor of Taiya Inlet also required a bathymetric survey to determine the exact length of cable needed which depended upon the bathymetry of the Inlets floor. The bathymetric survey also helped determine the feasibility of the project by evaluating the bathymetry at the landings and the composition of the Inlet's floor.

\subsection{PERMITS}

Initially we applied for permits from the following:

- U.S. Army Corps of Engineers for a Nationwide Permit 12 (NWP) \#D970592

- Alaska Dept. of Governmental Coordination for a Coastal Zone Management Program consistency determination, State ID \#AK 9709$11 \mathrm{JJ}$

- U.S. Forest Service for a special-use permit to use the Otter Creek Project site for a cable landing.

- Dept. of Natural Resources right-of-way easement (R/W/E) permit to use submerged lands.

The cable landing site in Skagway is owned by the City of Skagway. No permitting was required because the use of city property is covered under other agreements. However, because the White Pass \& Yukon Route Railroad is leasing land from the city that the vault and some of the line poles would be on, we requested permission to cross this land. Permission was granted. In addition, this land is subleased by the Alaska Industrial Development and Export Authority (AIDEA). We requested authorization to cross this land also. They responded with a 'no objection'.

Initially, the U.S. Forest Service requested that FERC determine if this project was within their jurisdiction because of the interconnection of the Goat Lake Hydro Project with the cable. This would have required a license amendment of the Goat Lake Project FERC license to place the submarine cable. FERC issued a "no jurisdiction determination."

All of the permits required public notices. No comments objecting to the submarine cable were received. After the cable was laid, AP\&T was required to have the right-of-way easement (R/W/E) assessed at the current market value for DNR to establish the annual fee. 


\subsection{PROJECT CONSTRUCTION}

\subsection{BATHYMETRIC SURVEY}

Excerpts from the final Bathymetry \& Side Scan Sonar Cable Route Survey, by Chris Ransome \& Associates is included below. The report was issued on June 6, 1997.

"The bathymetric and side scan survey took place on April 21-28, 1997. The bathymetry data was collected using an Innerspace 440/441 single beam dual frequency system, which is capable of collecting data both in shallow and deep water environments. This system is coupled with a DGPS positioning system via a computer using software designed especially for this real-time acquisition. Data was collected moving parallel with the shore centering between land masses to place the cable in the middle of Taiya Inlet and Chilkoot Inlet and in the deepest part of the channels. As the most important part of this survey was to develop a route and then determine cable length, all bathymetry data was reduced for tides to give the highest vertical accuracy. The vertical control was provided by using tidal transfers with predicted tide tables. In addition, all three landing sites (Haines, Otter Creek Project, Skagway) a land survey was done to give a full data set for a comlete cable route design. This data was done using DGPS and a Lasertrak with a computer to give a full 3-D line strength calculations."

"The side scan sonar survey was performed in conjunction with the bathymetric survey. The survey was performed utilizing the same navigation system and vessel as used for the bathymetric survey. The side scan sonar system used for the survey was a Klein digital slant correction system, model 595. The side scan sonar was integrated with an "ISIS" data processing system allowing for real-time geocoding of the digital data from the side scan sonar sensor as it was towed along the bottom. The bottom features were displayed both on the side scan sonar recorder and on the data processor's PC monitor. The digital data was stored on optical disk for archive and generating a digital strip chart."

"During the field data collection the side scan sonar was towed along 100 meter track lines with the sonar scanning at a 200 meter swath. Using this configuration, a 200 percent overlap of side scan sonar coverage of each line was accomplished. Upon completion of the survey, a digital strip chart of the surveyed area was prepared. The digital strip chart includes geocoded imagery of the water bottom features and can be quickly recovered from the archive data."

"This survey has proved to be one of the most challenging for our team in recent years due to the isolation and remoteness of the survey area. The 
area in question for study contained very deep water depths, up to $1500^{\prime}$, with some very steep channels. This caused considerable need for monitoring the bathymetry data so as to ensure proper bottom tracking. In addition, the side scan sonar fish was towed at layout lengths of up to $2500^{\prime}$. The high mountains were initially a concern on the quality of GPS satellite signal reception, but the full GPS satellite constellation is in place and the survey encountered no problems with signals at any time."

\subsection{PLACING THE SPLICE VAULTS}

The splice vaults were pre-cast concrete, 8-foot diameter, water-main manholes type structures, as shown in Figure 9 for Haines and Skagway. In Figure 10, the splice vault for the Otter Creek Project is shown. The splice vault lid has an HS-20 standard load rating which allows heavy vehicles to drive over it. This rating indicates that this structure is very strong and will withstand significant events of nature. AP\&T personnel placed the splice vaults at the Skagway, Haines, and Otter Creek Project landings, prior to the cable laying ships arrival, by utilizing a barge and excavator. AP\&T personnel also performed the trenching for laying the cable to the splice vaults through the intertidal zone with a backhoe. The trenching was completed during minus tides to provide the maximum amount of protection to the cable by burying it with rock. About 240 -feet of 8 -inch high density polyethylene chloride (HDPE) pipe was used at each site to sheath the cable as it crossed the intertidal zone for protection. Approximately 80 -feet of 12 -inch steel pipe was used at each site to sheath the cable as it crossed the above mean high tide zone for protection.

\subsection{LAYING THE CABLE}

The schedule for laying the cable was adjusted depending upon Pirelli/Jacobson, Inc. ships availability. A diagram in Figure 11 shows the ship plan and profile that laid the cable. Photographs of the ship laying the cable are shown in Appendix B - Project Photographs. The cable was first shipped from England to Seattle, Washington. From there a special ship was configured to lay this particular cable project. The ship arrive June $27^{\text {th }}$ and began laying the cable from the Otter Creek Project site to Skagway. Once this portion of the cable was laid the next phase was to lay the second piece of cable from the Otter Creek Project splice vault to Haines. The cable was completely laid by July 3,1998 . Photographs of the cable being laid are in Appendix B - Project Photographs. AP\&T personnel then spliced the cable to both systems in Haines, Skagway, and at the Otter Creek Project site, as shown in Appendix B - Project Photographs. On August 25, 1998 the cable was energized and Haines began operations with $100 \%$ hydroelectric power. One-line diagrams of both Haines and Skagway are included in Appendix A as well as other project diagrams. 
To complete the installation of the cable the areas trenched were returned to normal appearances and signs warning of this potential navigational hazard were placed at each of the cable landings.

\subsection{PROJECT COSTS}

\subsection{COST ESTIMATES}

Costs for the project are itemized below:

- Purchase price for cable

$\$ 3,000,000$

- Transportation of cable

$\$ 600,000$

- Cable installation

$\$ 1,550,000$

- Kasidaya Creek Landing (Otter Creek Project)

$\$ 110,000$

- AP\&T Costs

$\$ 600,000$

Funds for off-setting the total cost of this project are as follows:

- Federal Grant

$\$ 1,000,000$

\subsection{APPENDICES}

Appendix A: Project Figures

Appendix B: Select Project Drawings

Appendix C: Project Photographs 


\section{HAINES - SKAGWAY \\ SUBMARINE CABLE INSTALLATION \\ TECHNICAL REPORT}

APPENDIX A

PROJECT FIGURES

(THE FIGURES REFERENCED THROUGHOUT THIS DOCUMENT) 
FIGURE 1: PROJECT VICINITY MAP

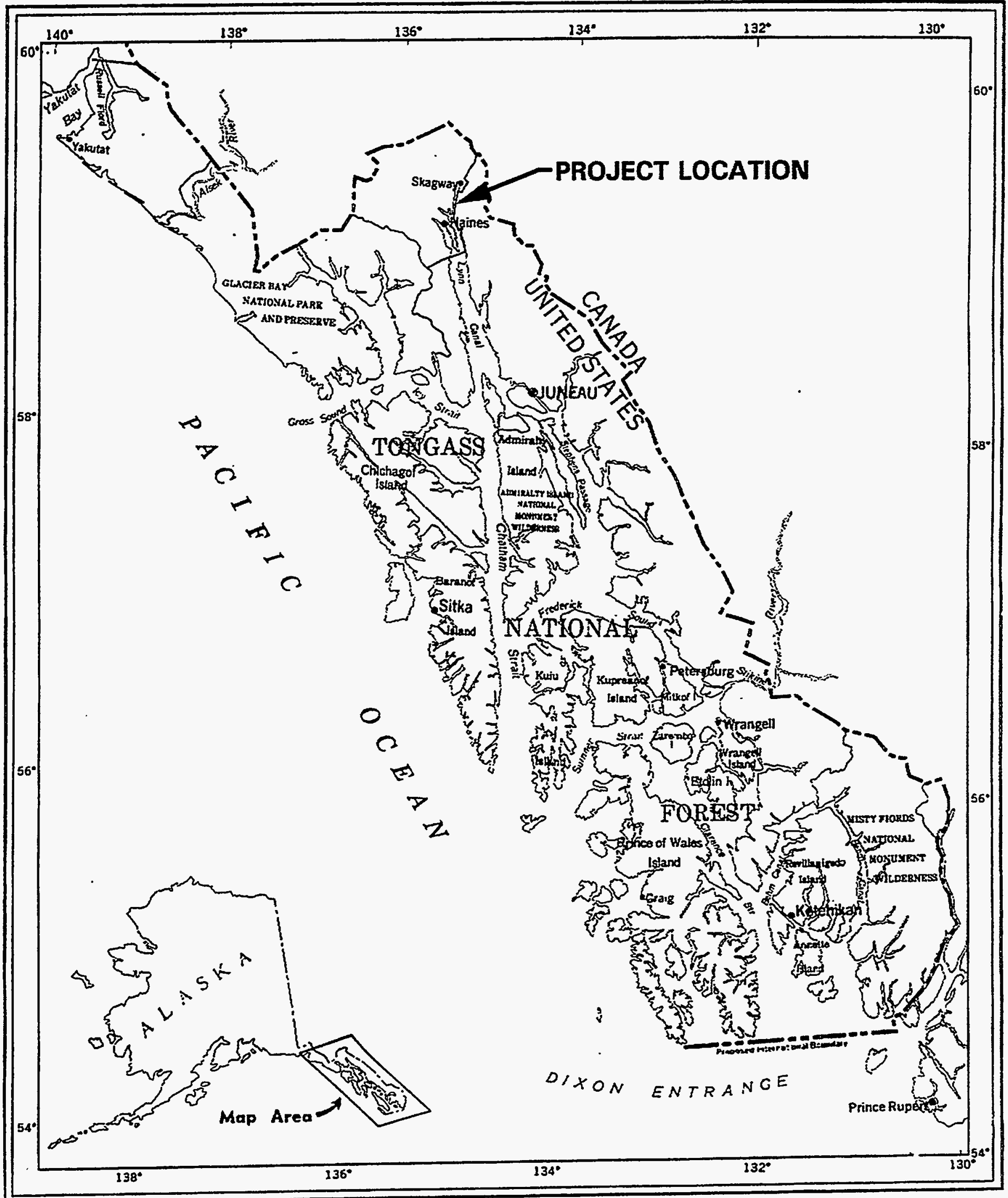




\section{FIGURE 3}

PIRELL

ALASKA POWER \& TELEPHONE CO.

040ess HAINESSKAGWAY CROSSING

\section{SUBMARINE COMPOSITE CABLE CROSS SECTIONAL AREA}

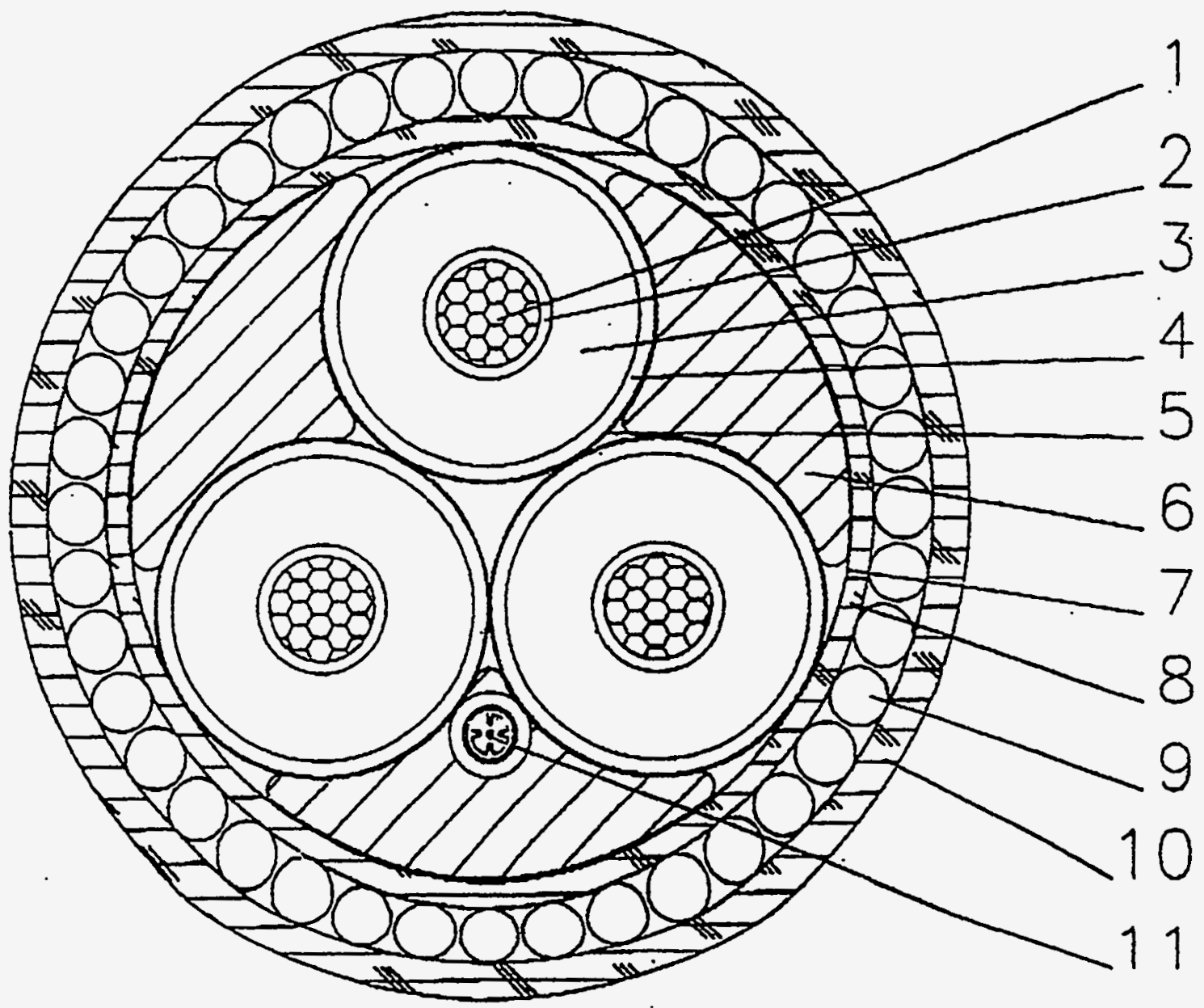

\section{Not to scale}

1. Tinned Copper Conductor

2. Semi-Conducting Conductor Shield

3. EPR insulation

4. Semi-Conducting Conductor Shield

5. Metallic Shiold

6. Polypropylene Fillers

7. Binder Tape

8. Polypropylene Bedding

9. Galvanised Steel Wire Armour

10. Polypropytene Serving 


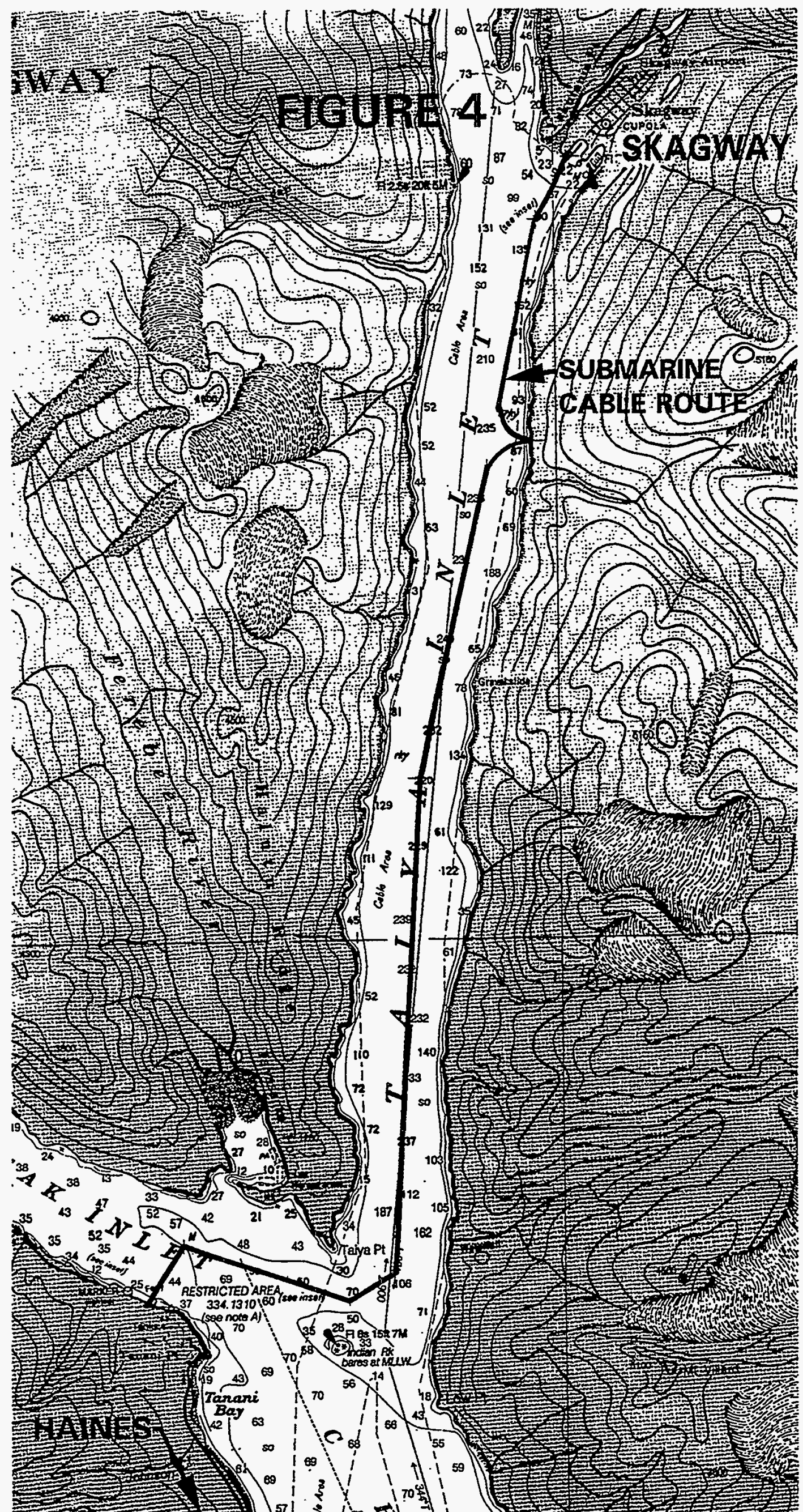




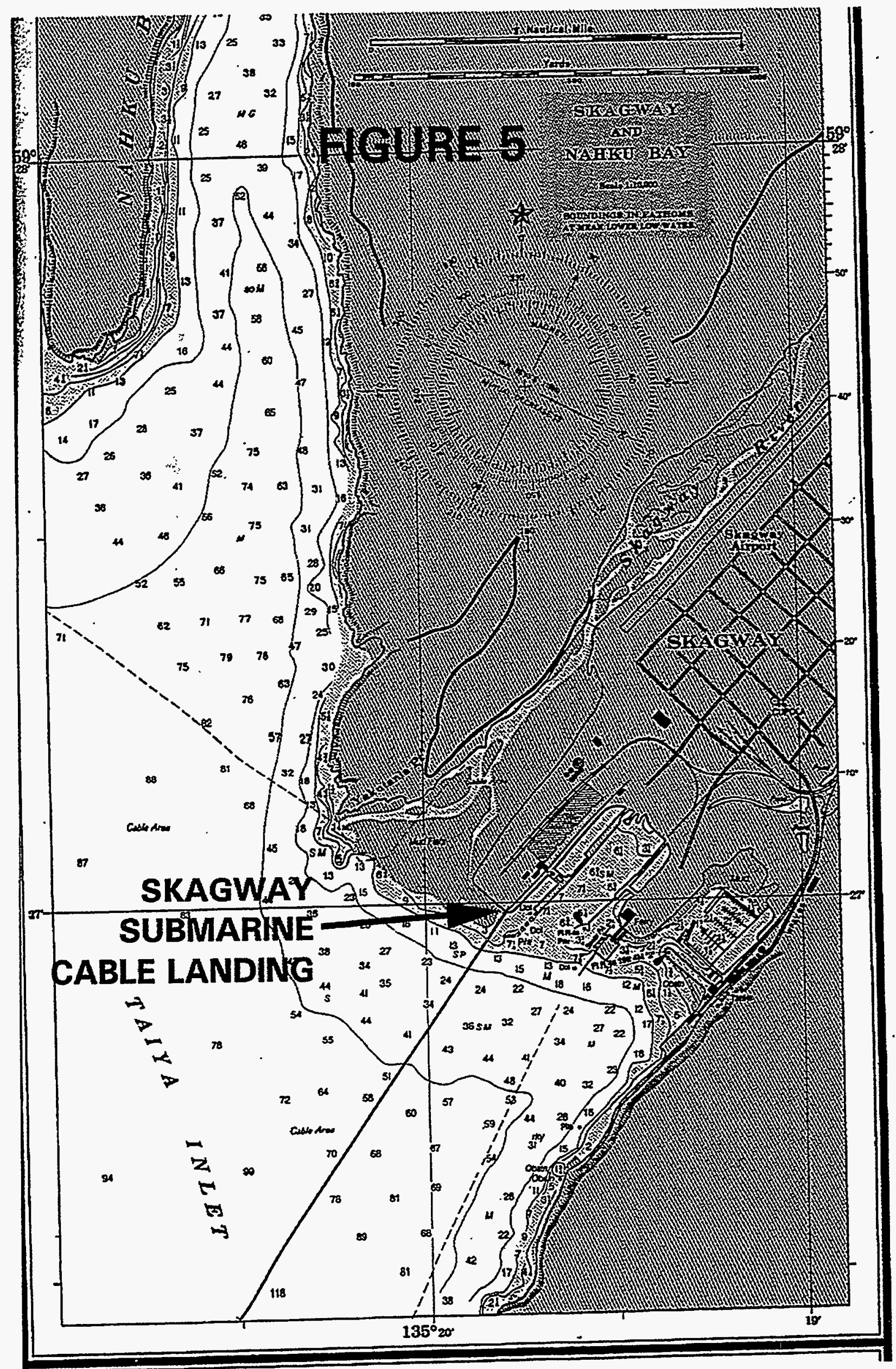




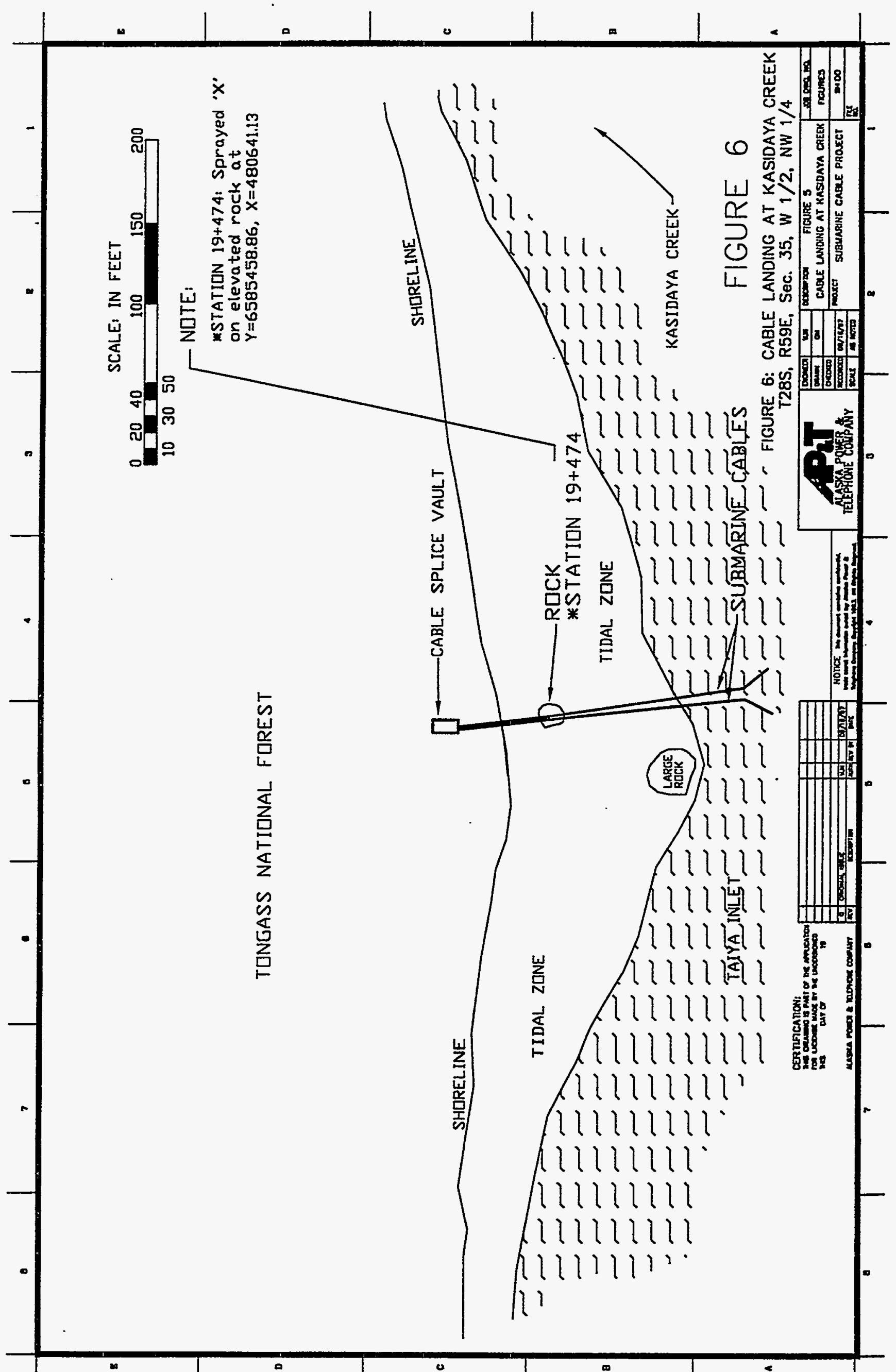




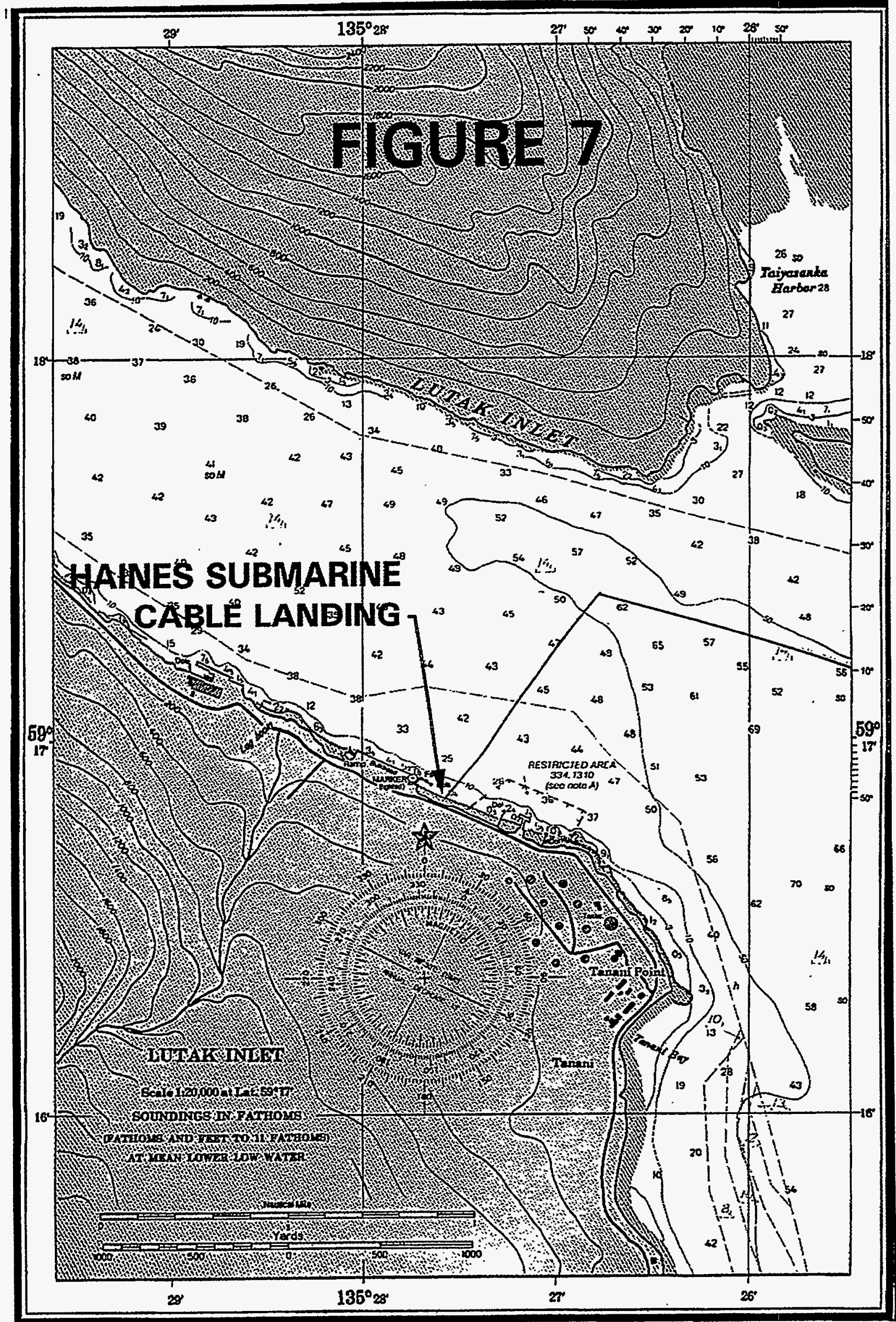




\section{FIGURE 8}

PROPOSED CABLE LANDING DESIGN FOR SKAGWAY AND HAINES

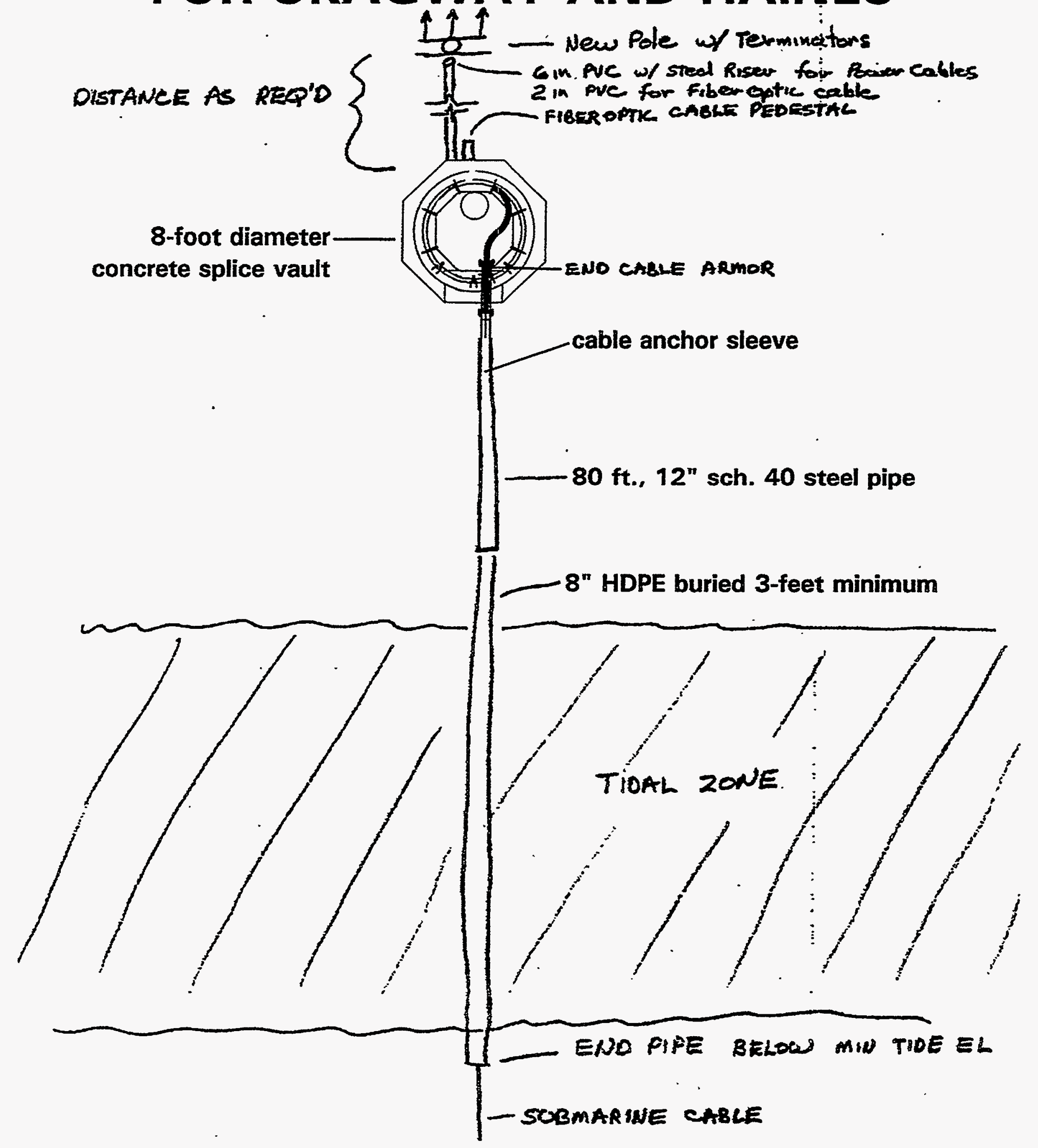




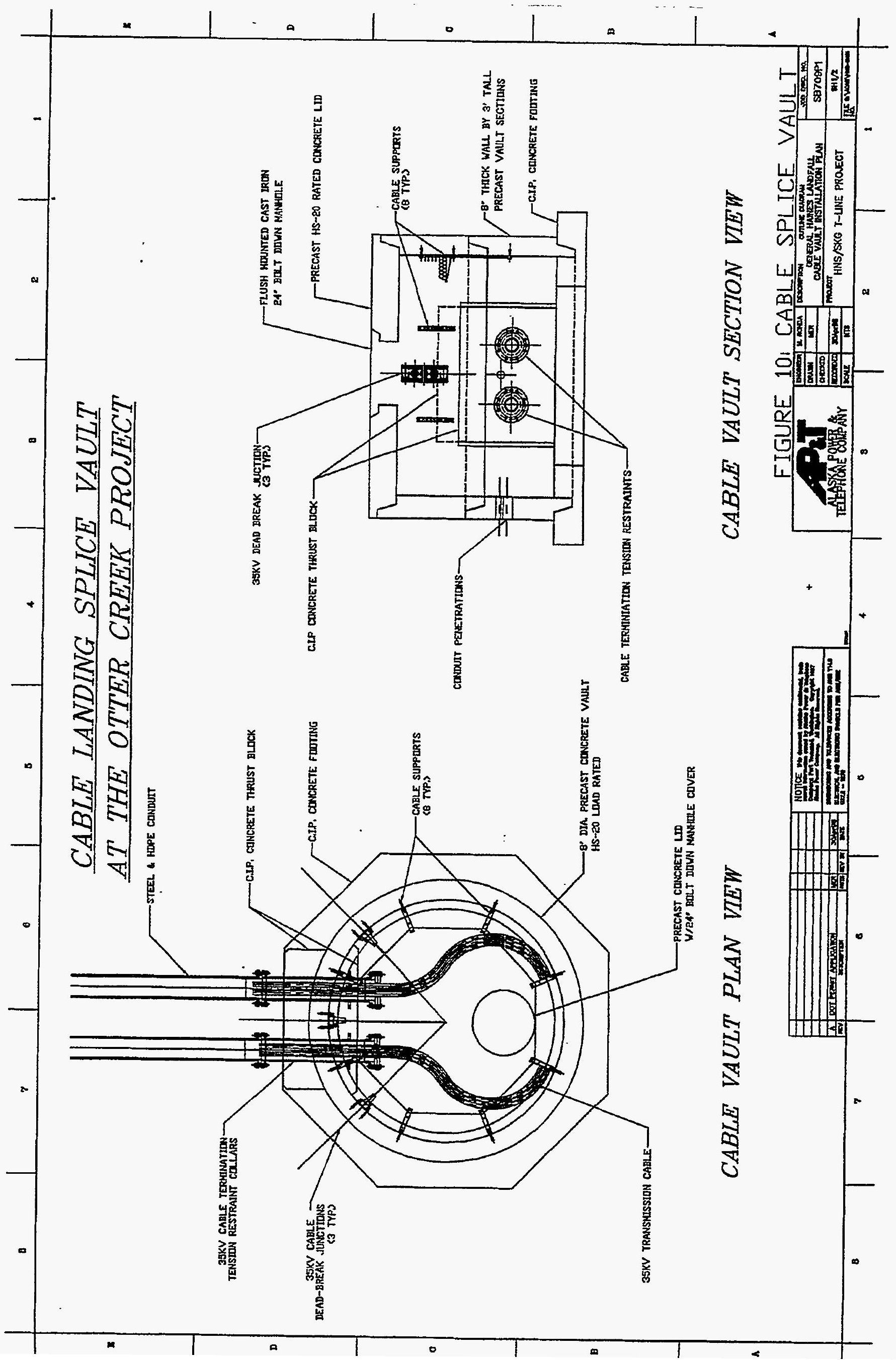



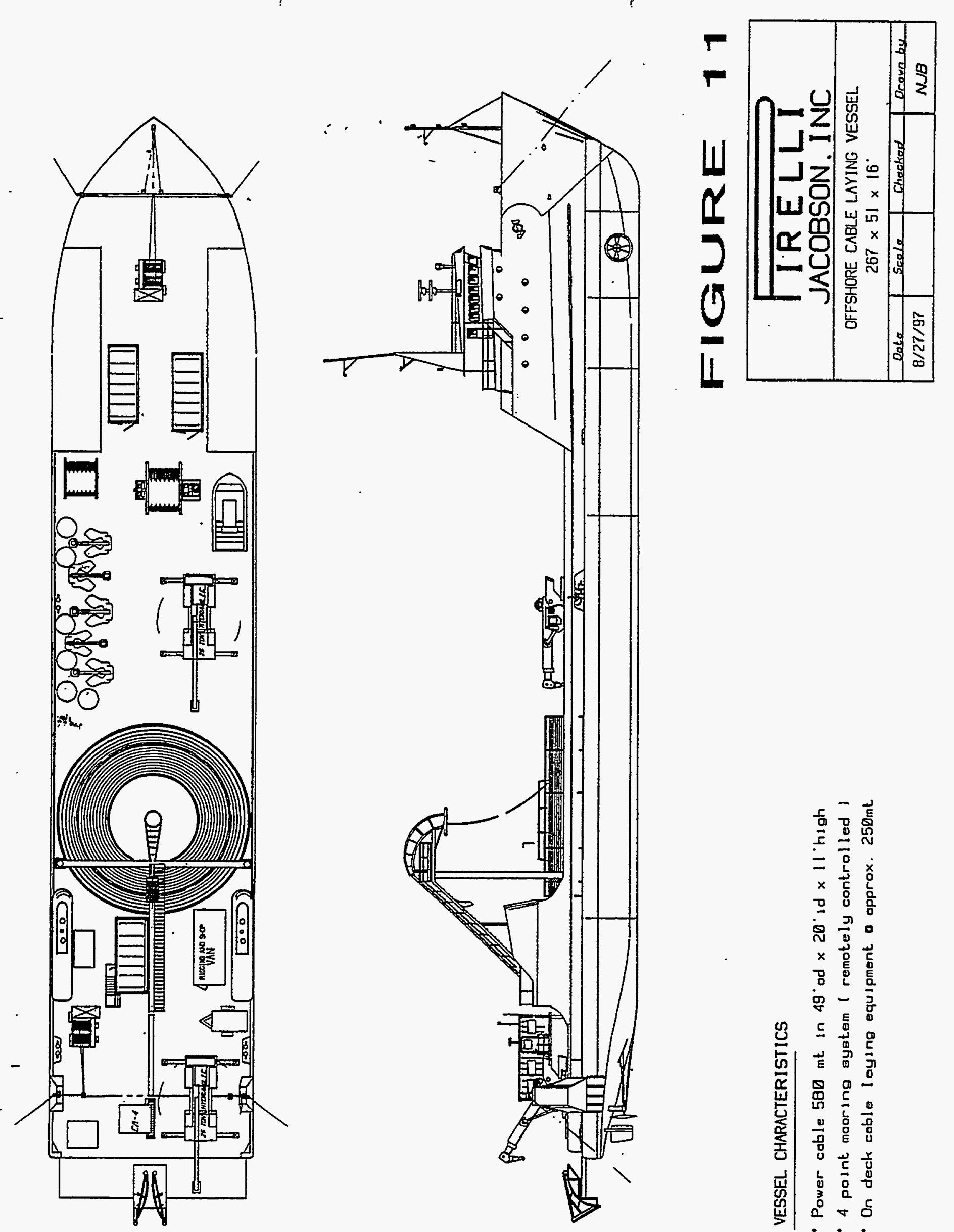

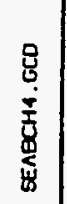

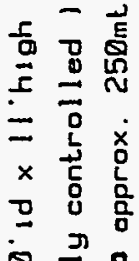

กิ

$\times$ 继

उ

守 - $\overrightarrow{\bar{\sigma}}$

包

氙| है

岕罢

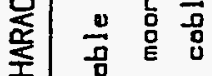

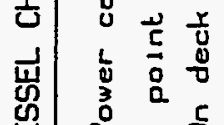

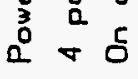




\section{HAINES - SKAGWAY \\ SUBMARINE CABLE INSTALLATION \\ TECHNICAL REPORT}

APPENDIX B

SELECT PROJECT DRAWINGS

(DRAWINGS SHOWING AS-BUILT INFORMATION) 


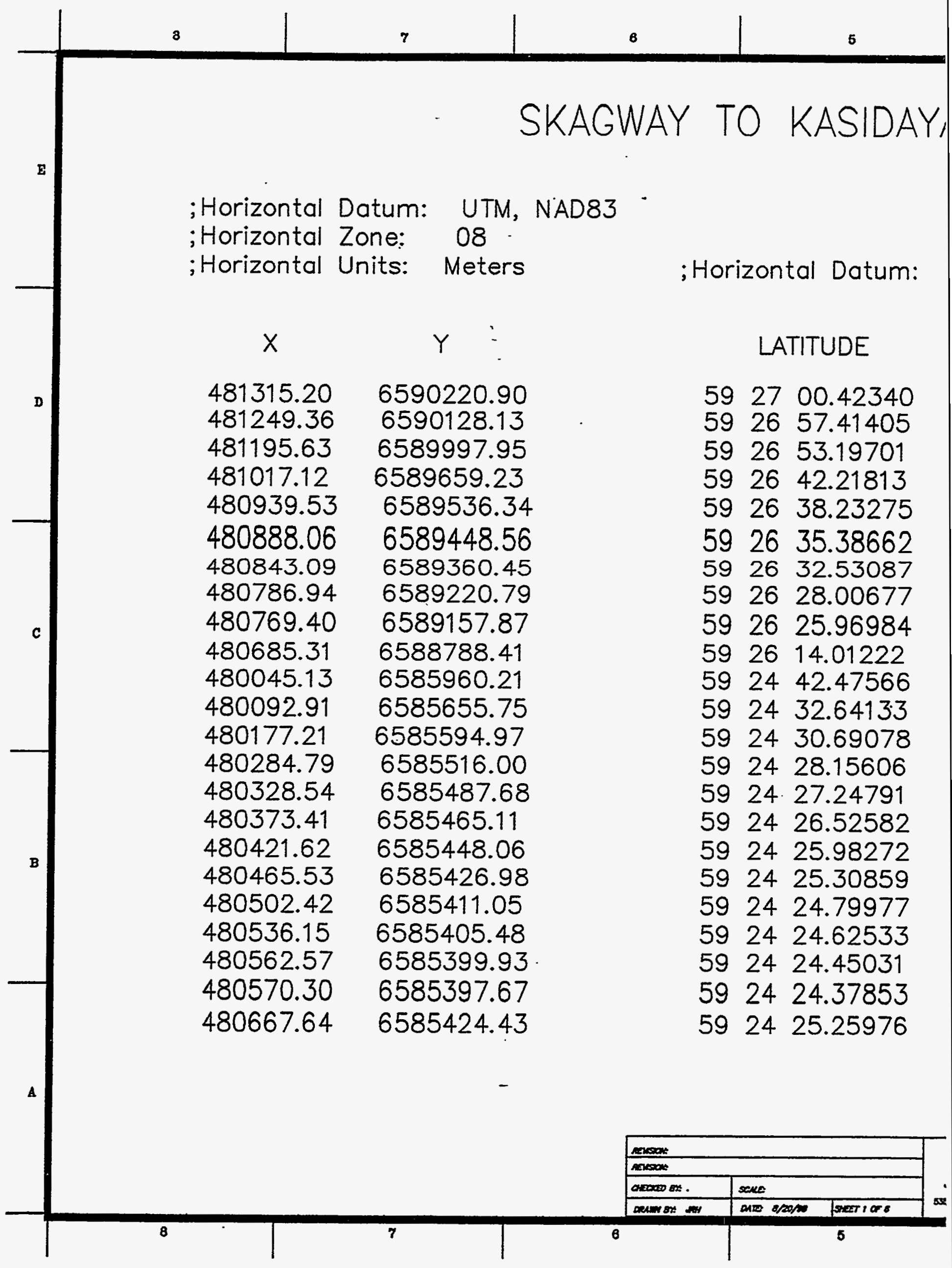




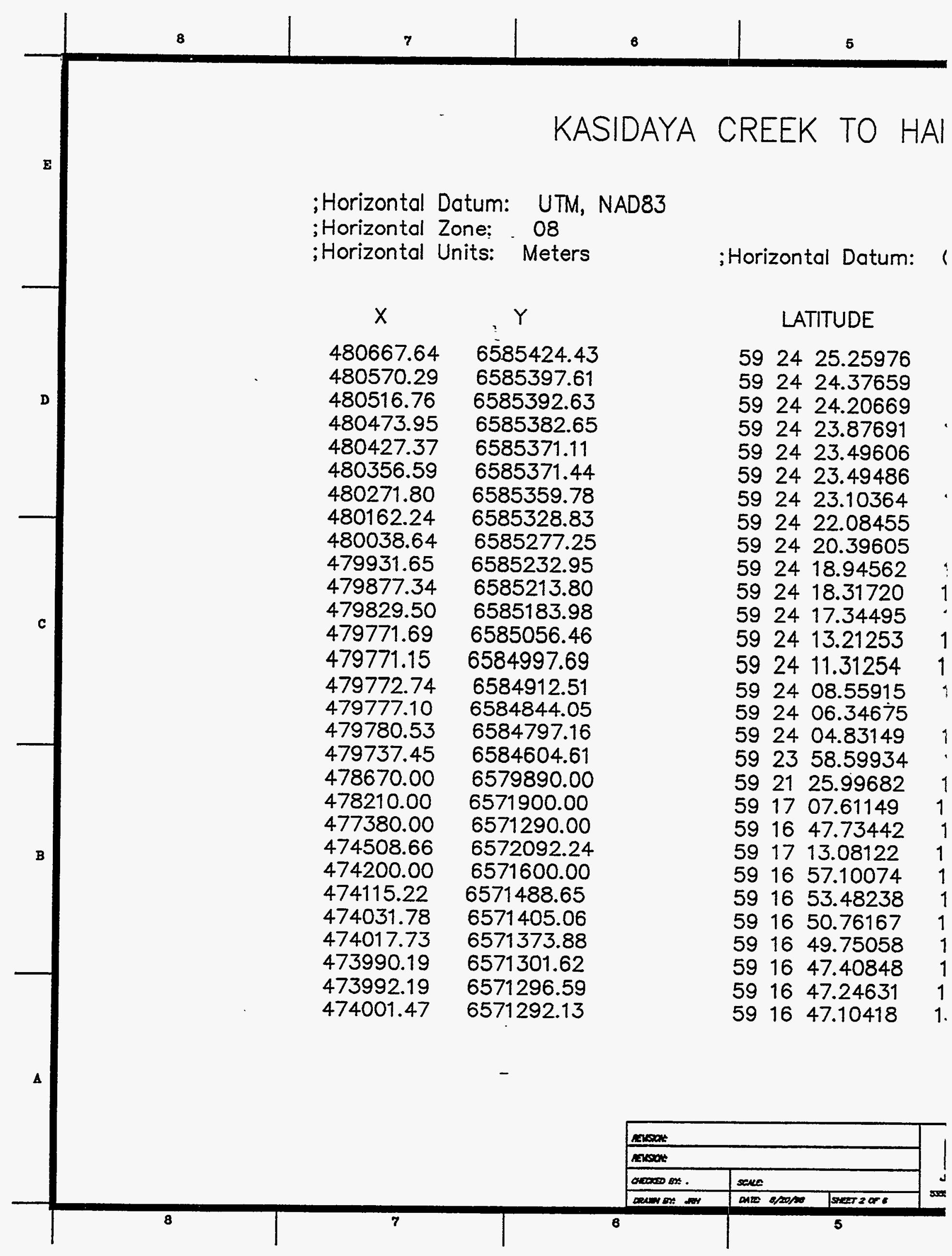




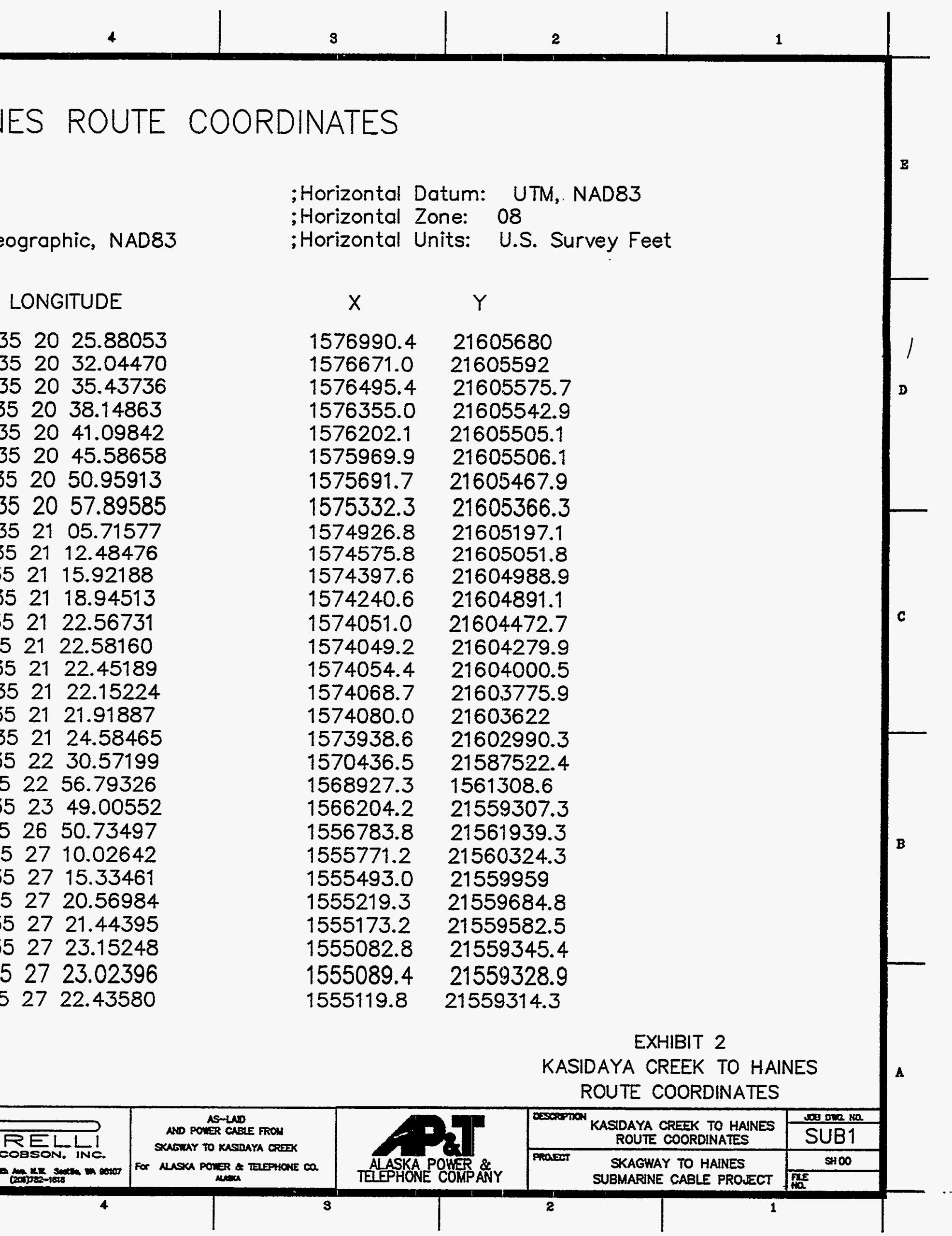




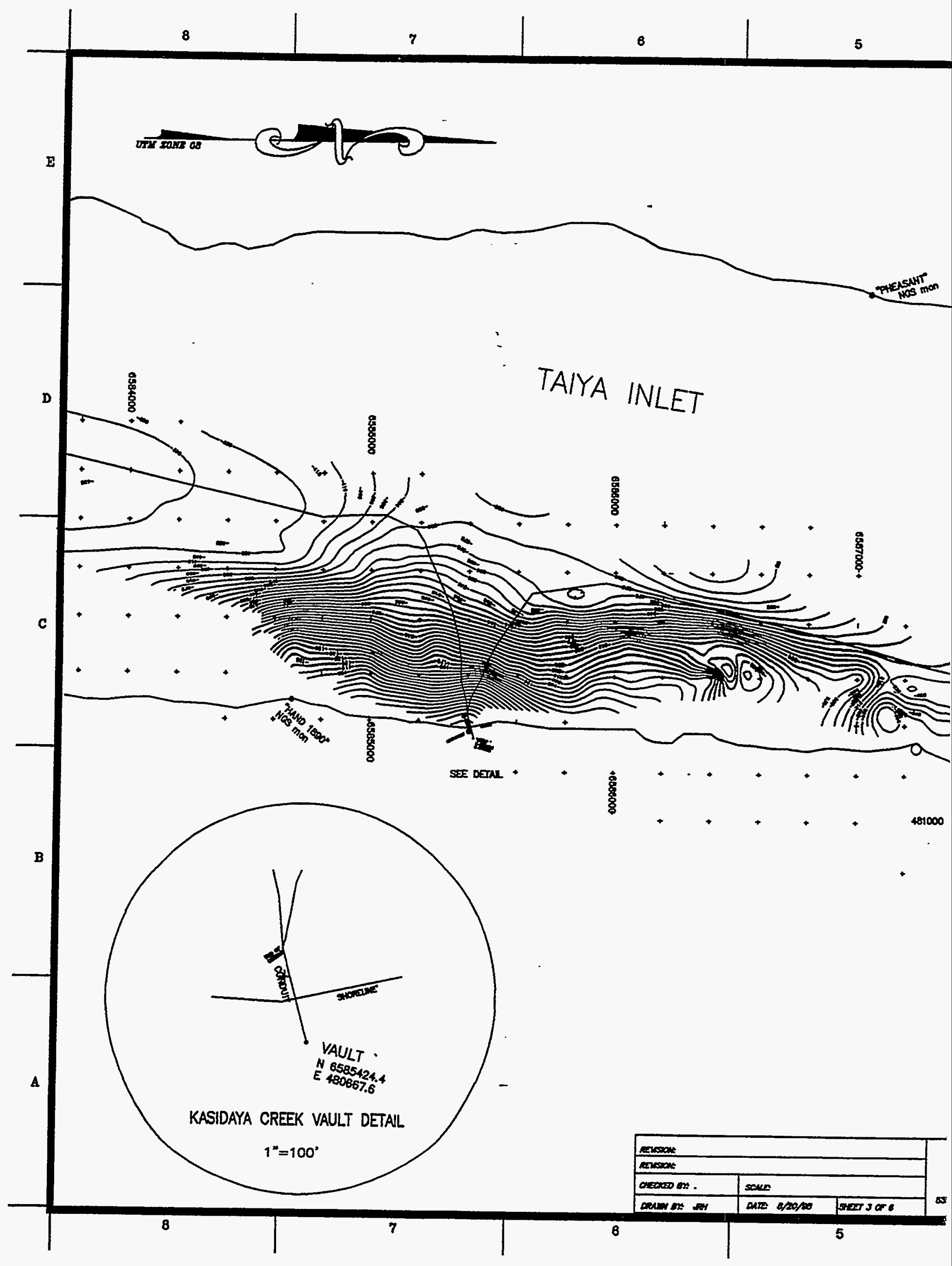




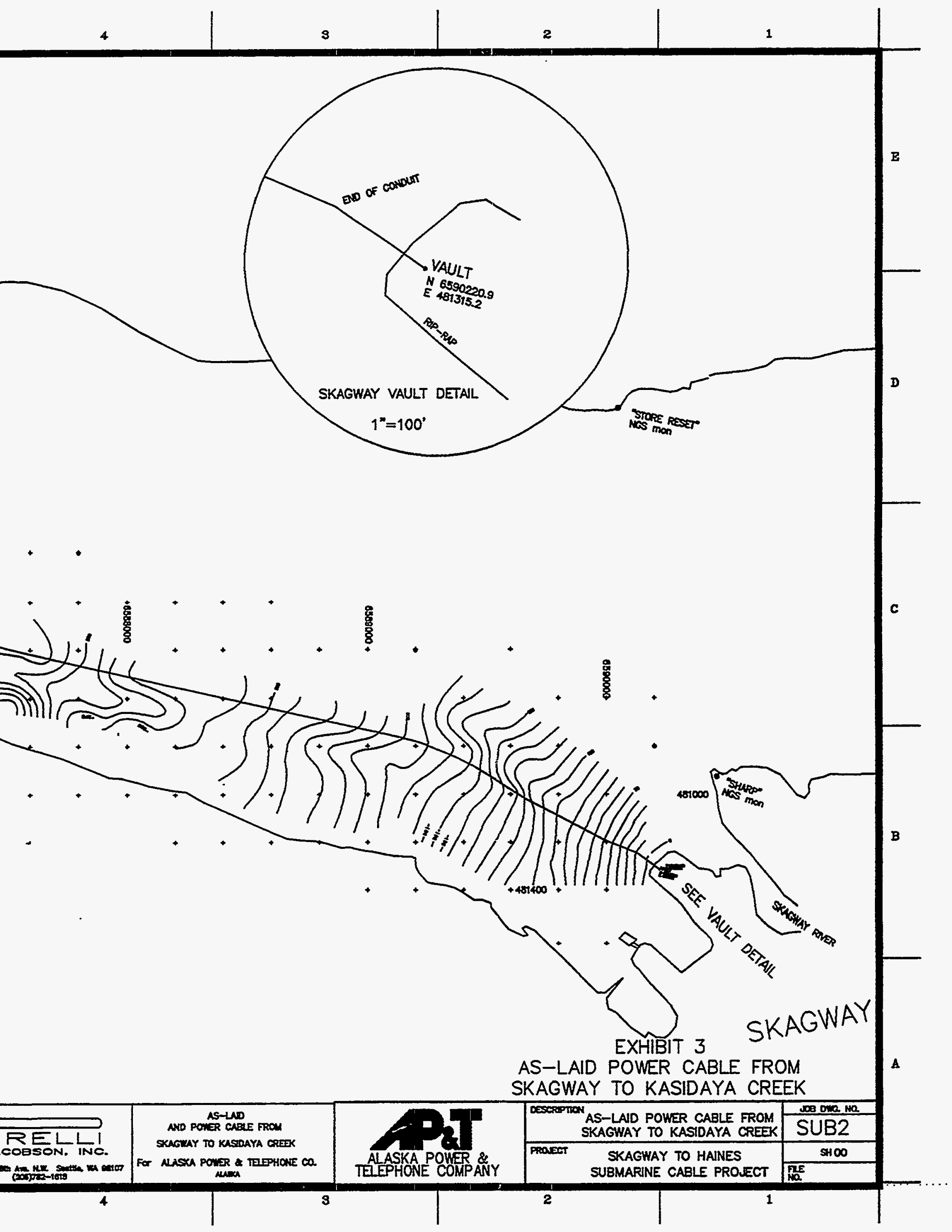




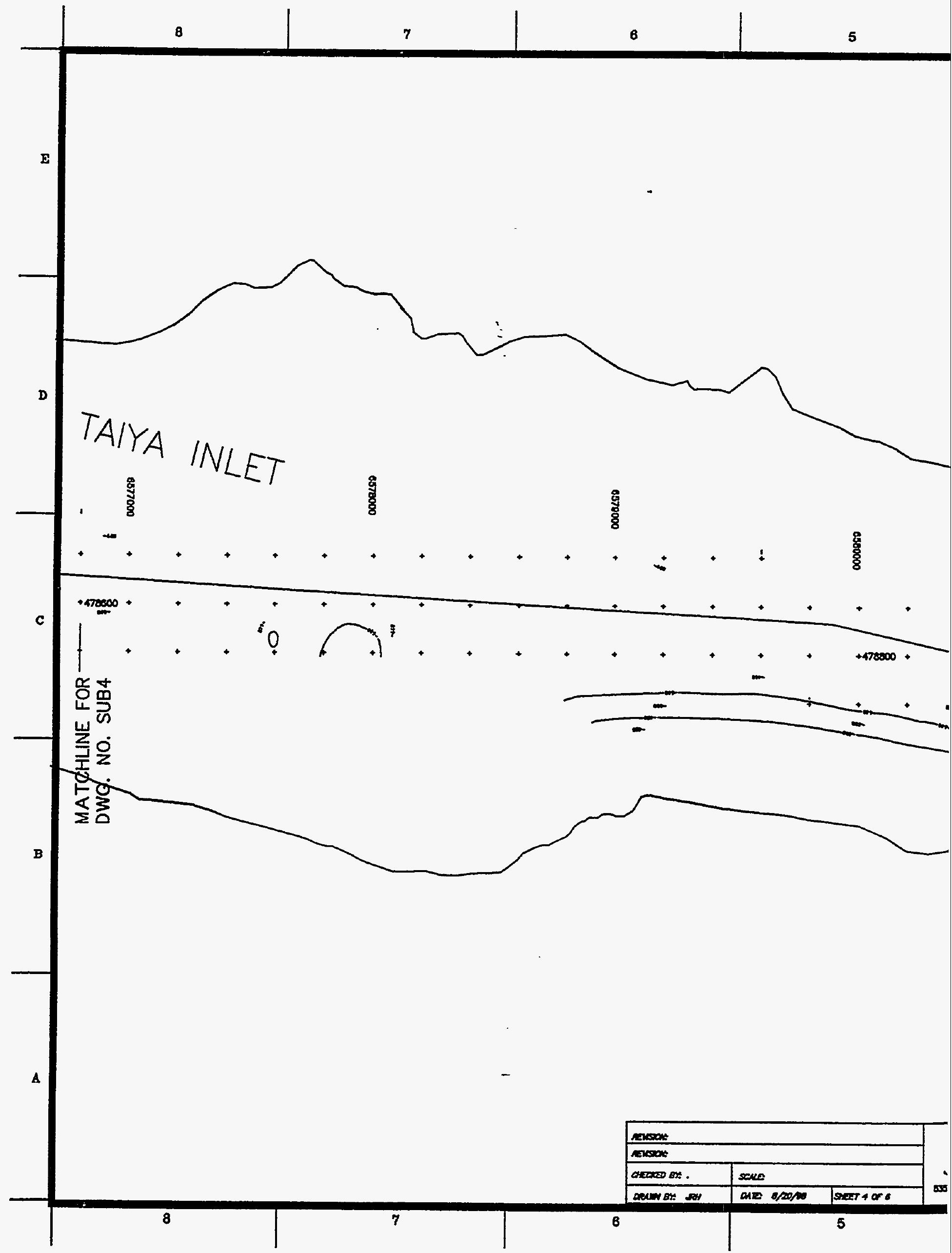




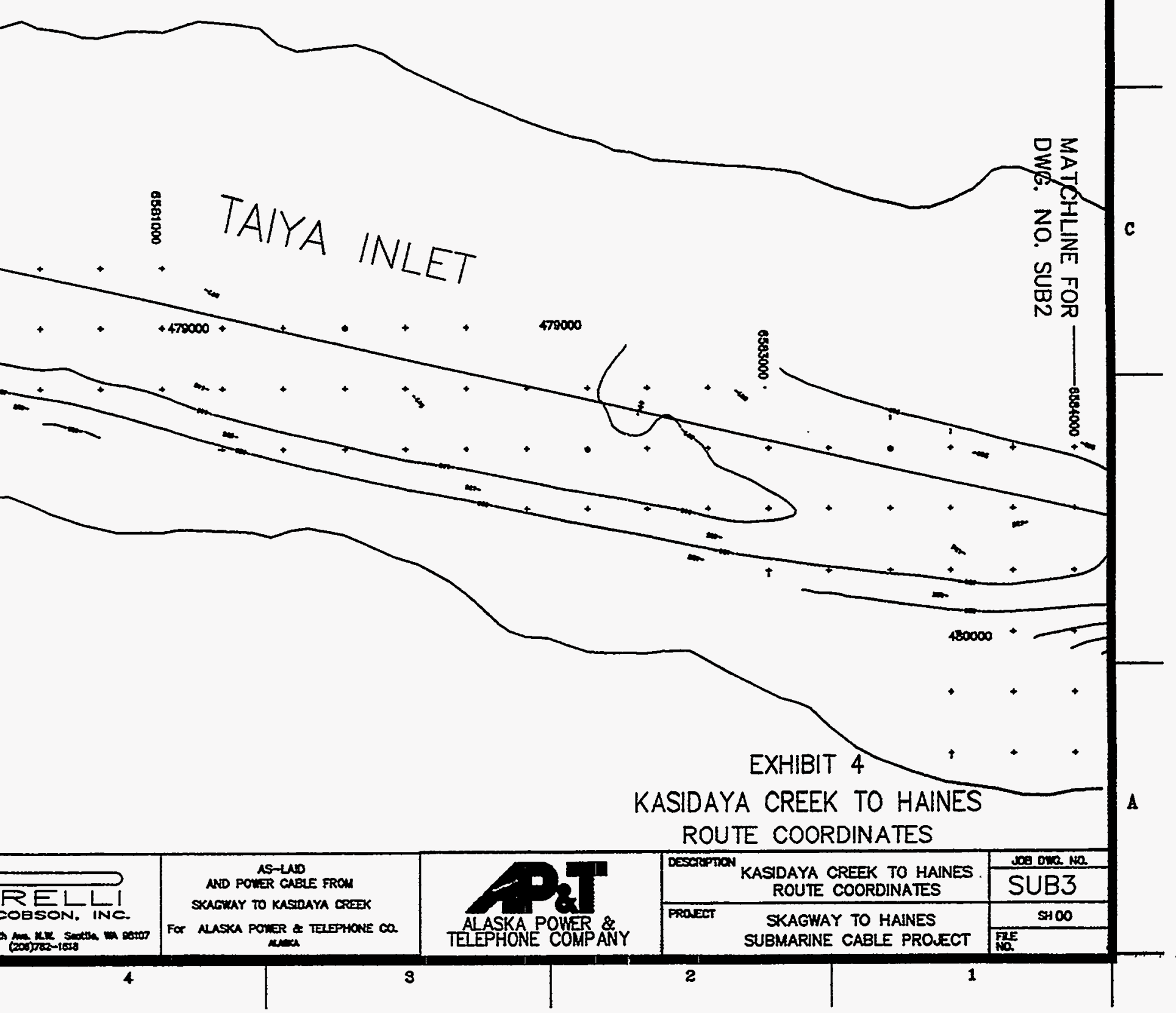




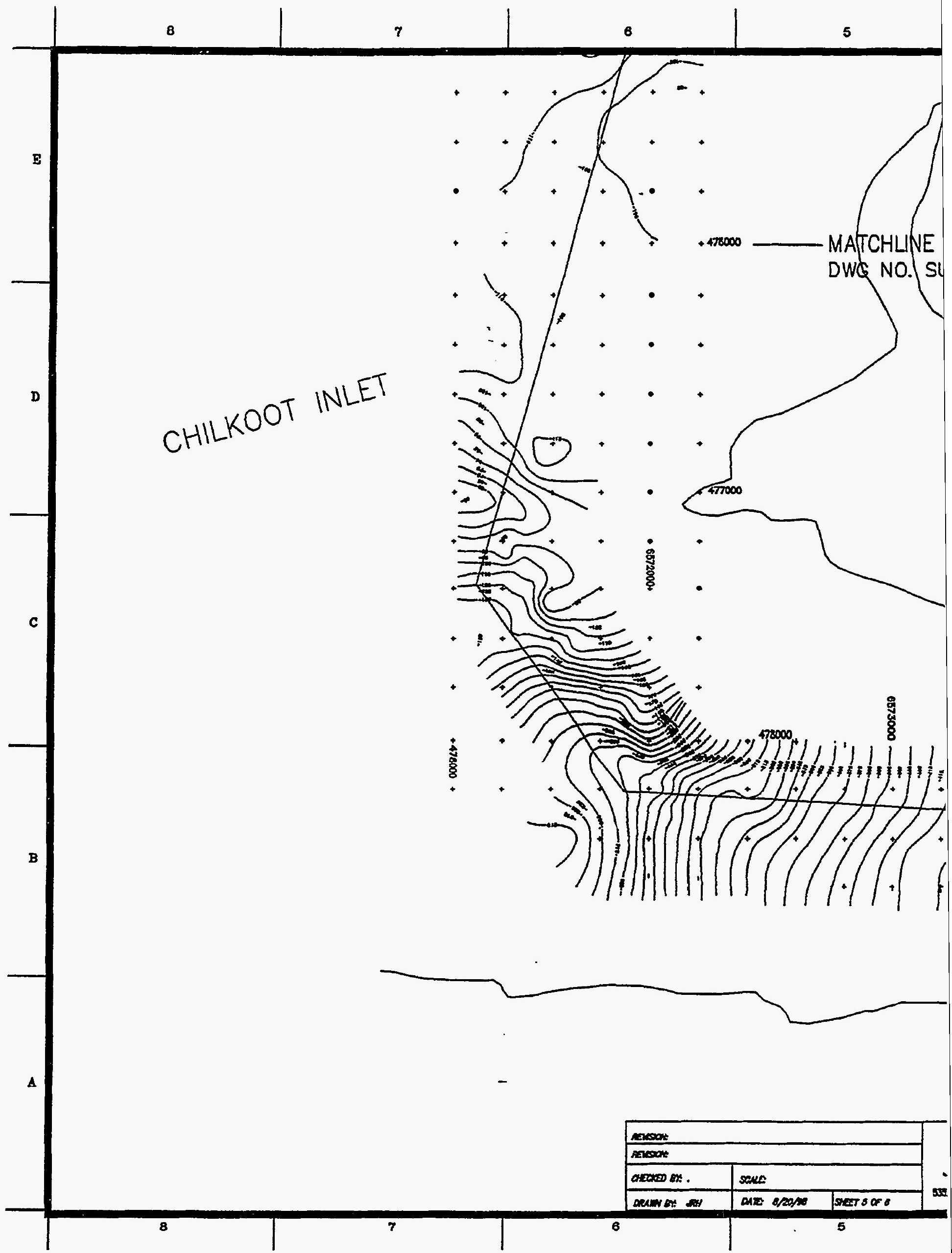




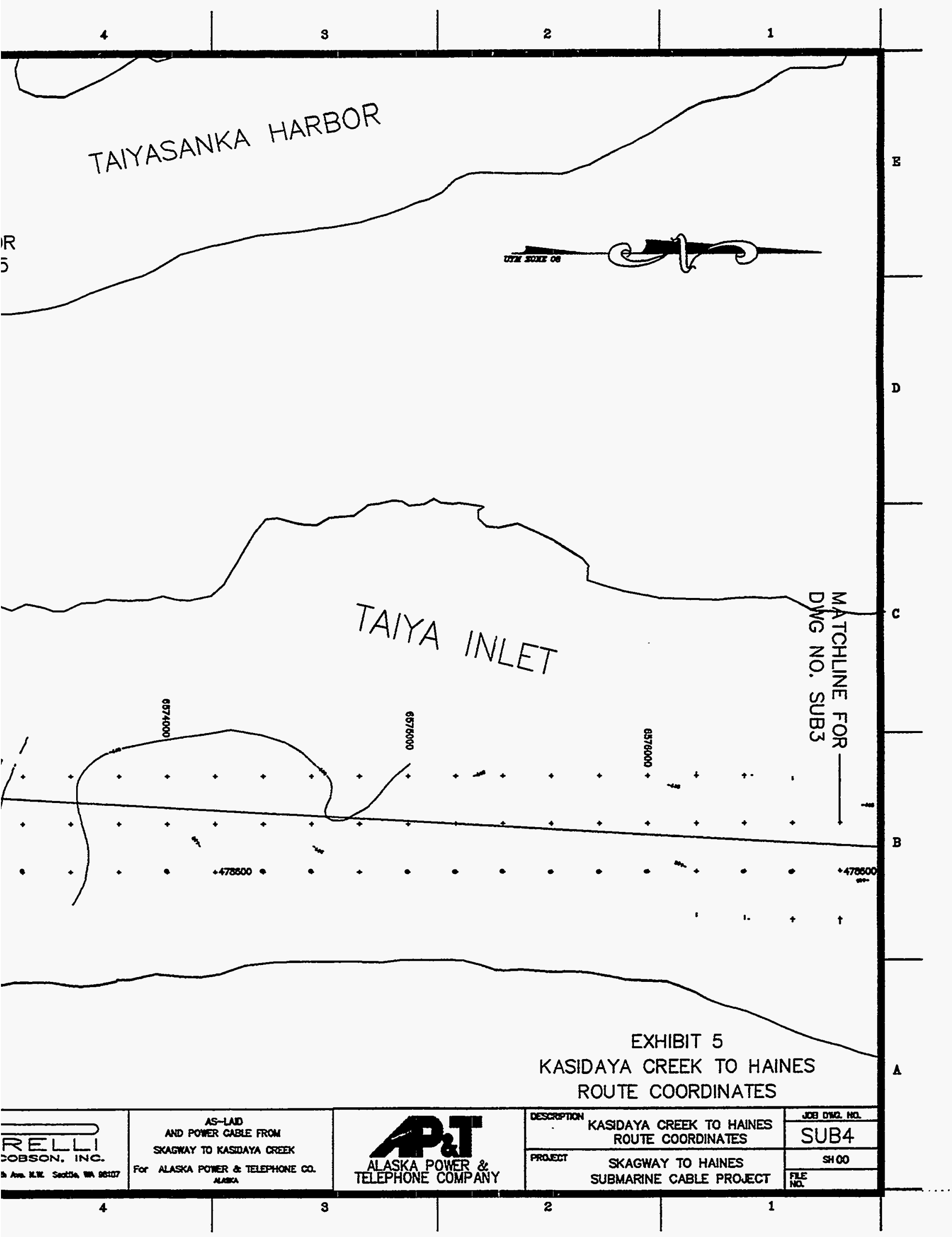




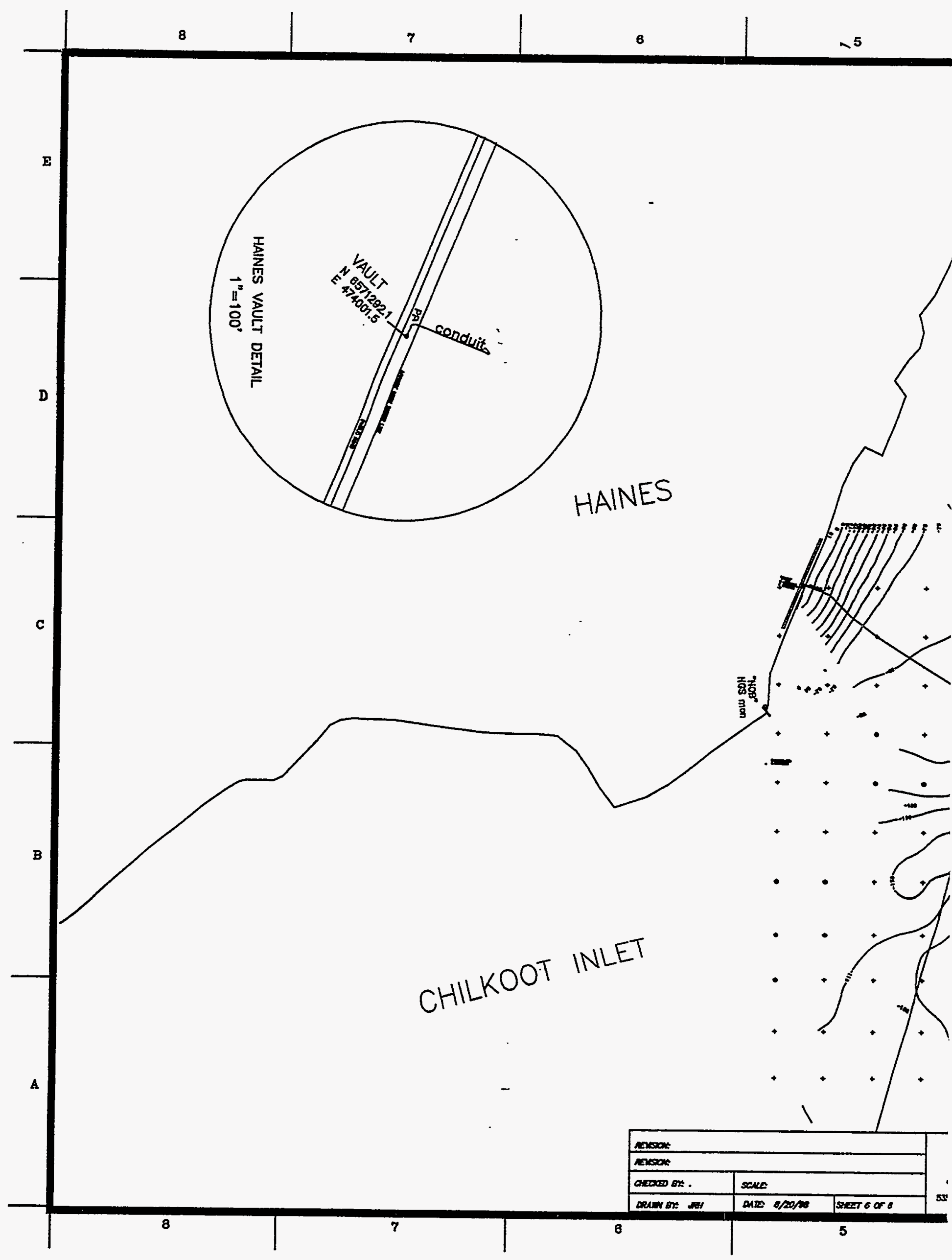




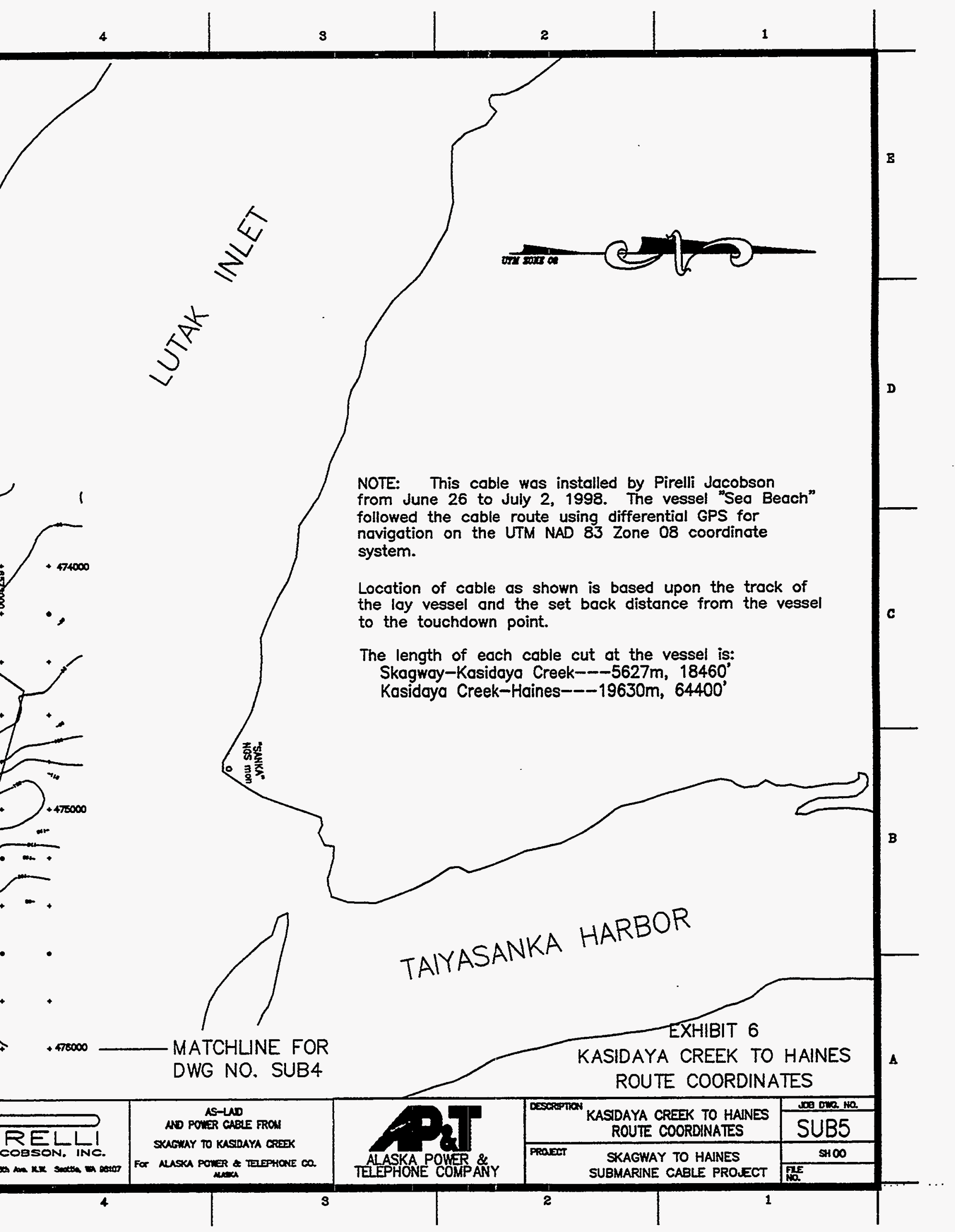




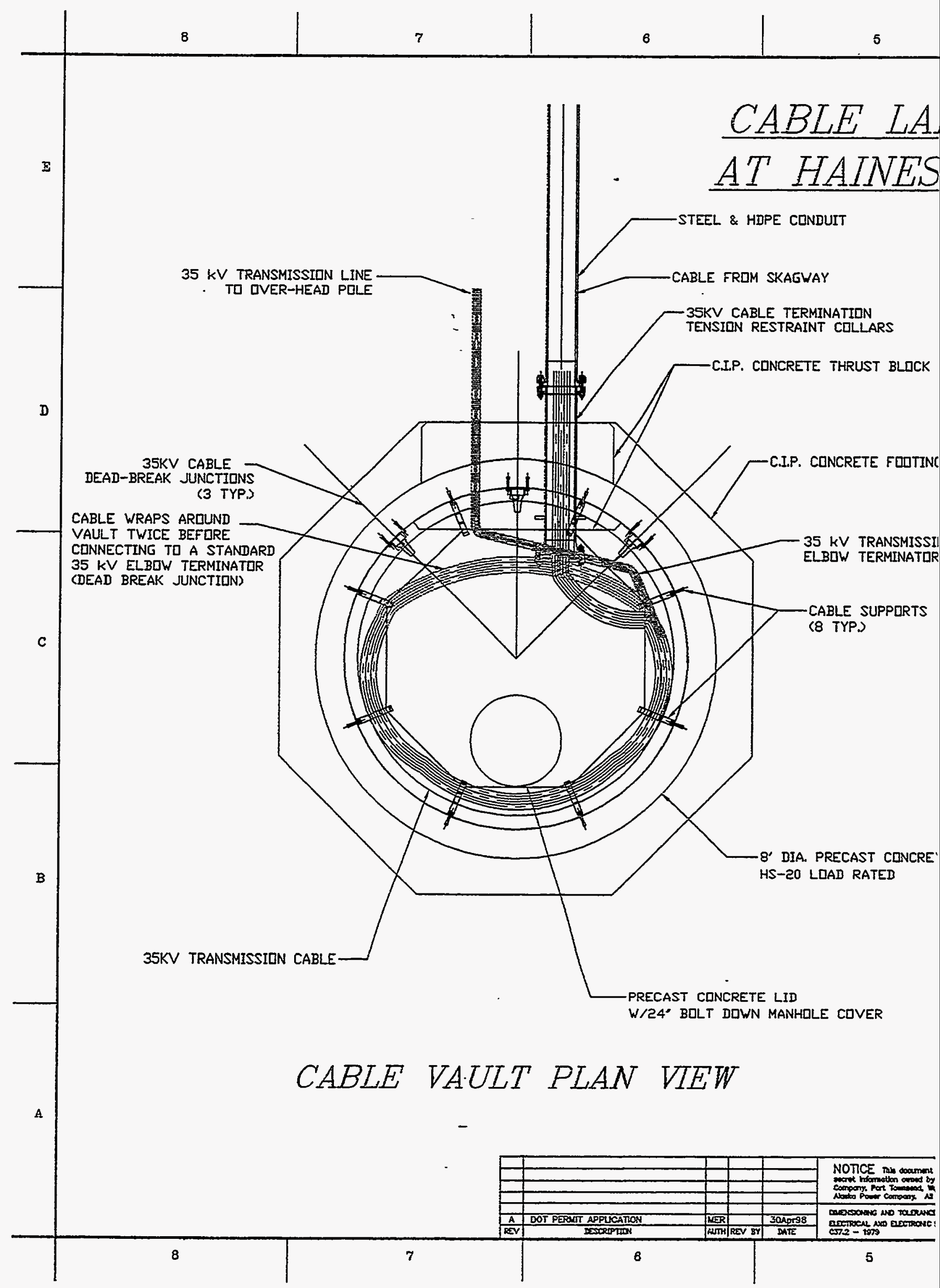




\begin{tabular}{l|l|l|l|l}
\hline+1 & 3 & 2 & 1 & \\
\hline
\end{tabular}

DING SPLICE VAULT

$A N D$ SKAGWAY

LINE FRDM

] POLE

$35 \mathrm{kV}$ ELBOW TERMINATOR (3 TYP.)(DEAD BREAK JUNCTIDN)

VAULT

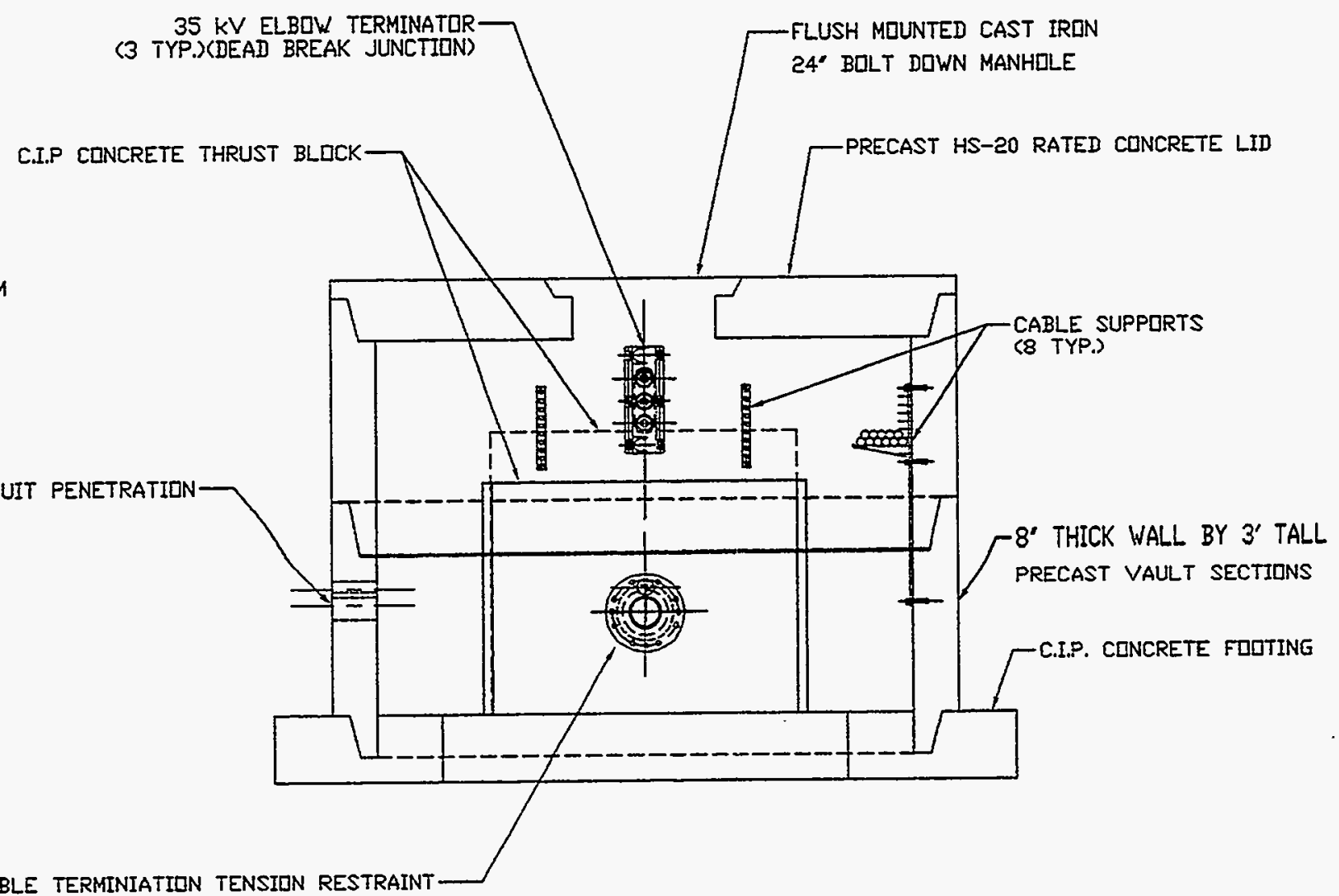
24" BOLT DOWN MANHIIL

CABLE TERMINIATIDN TENSIDN RESTRAINT

CABLE VAULT SECTION VIEW

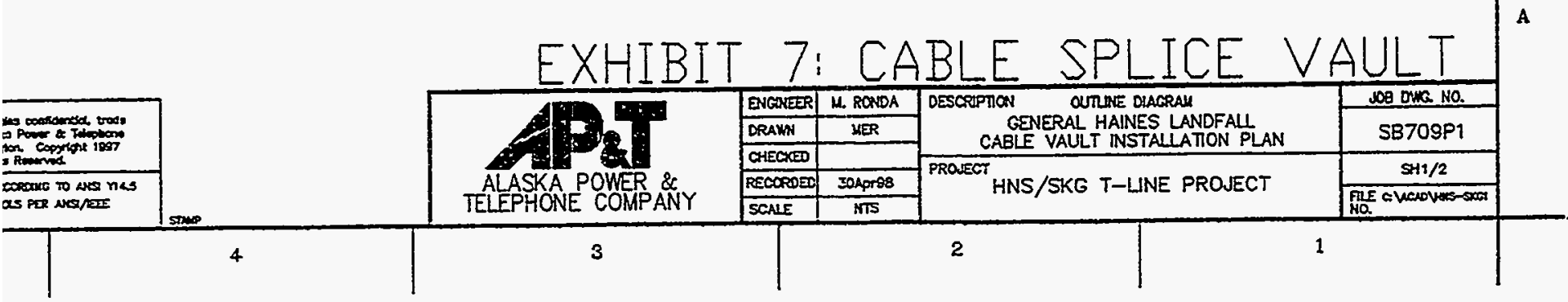




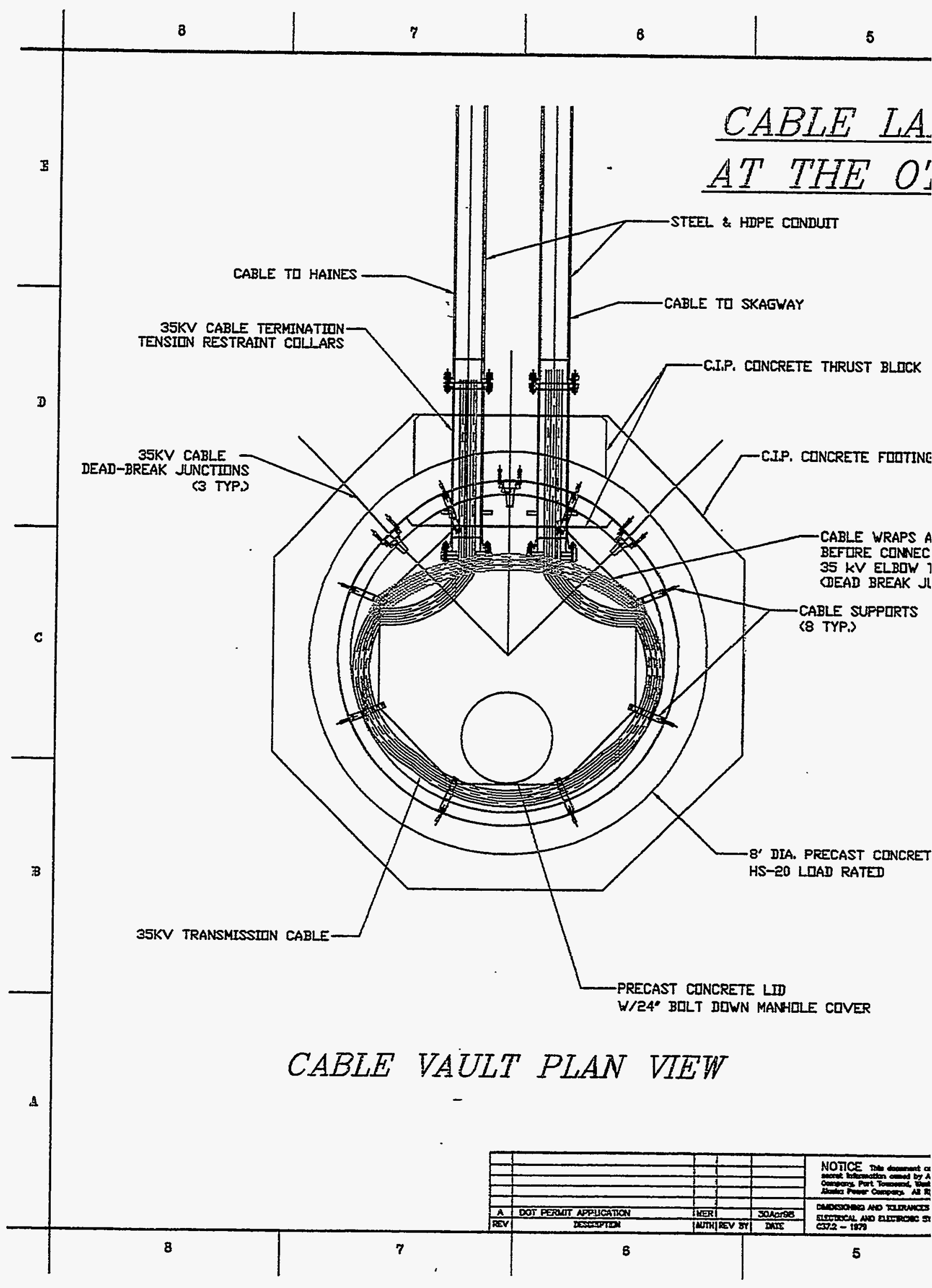




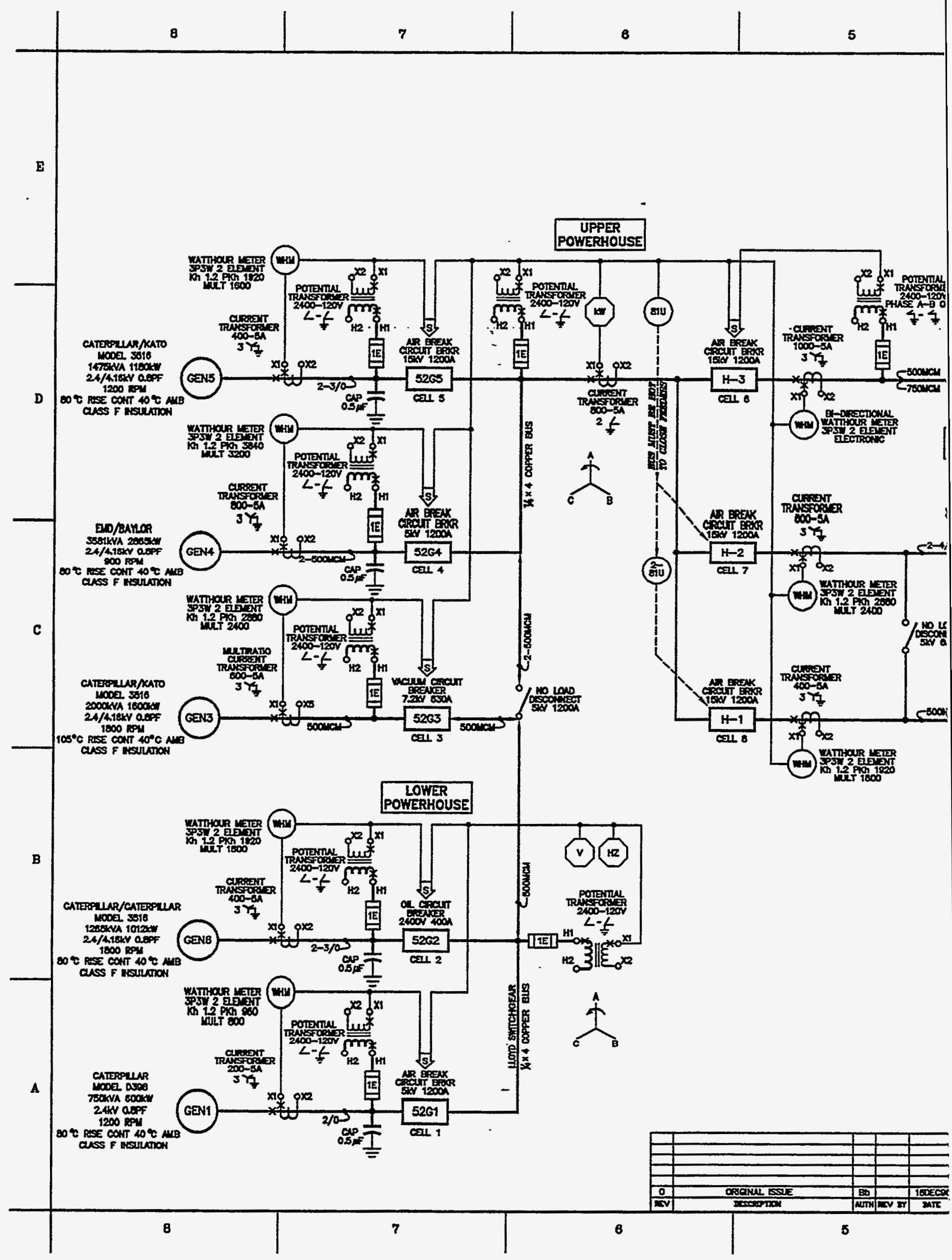




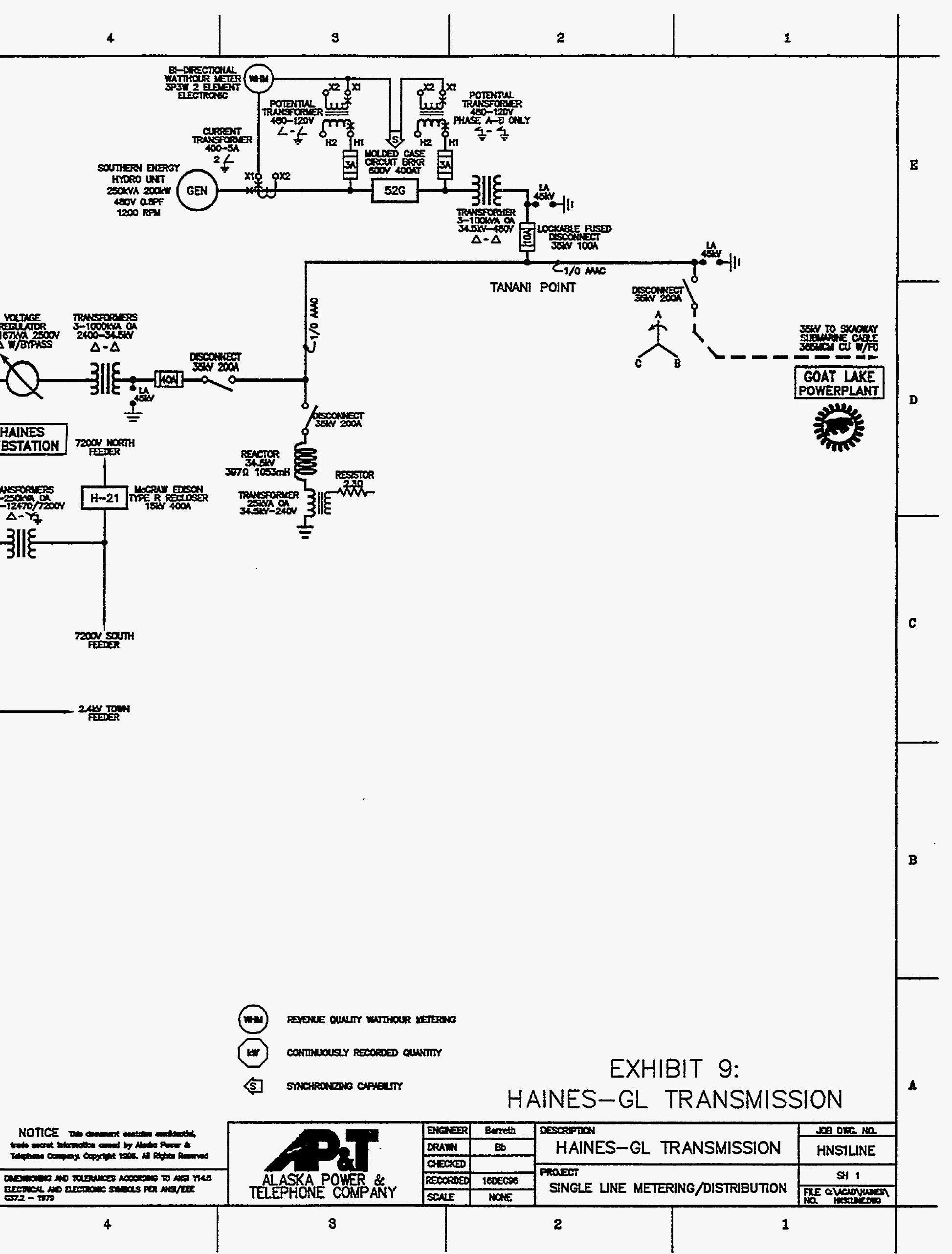




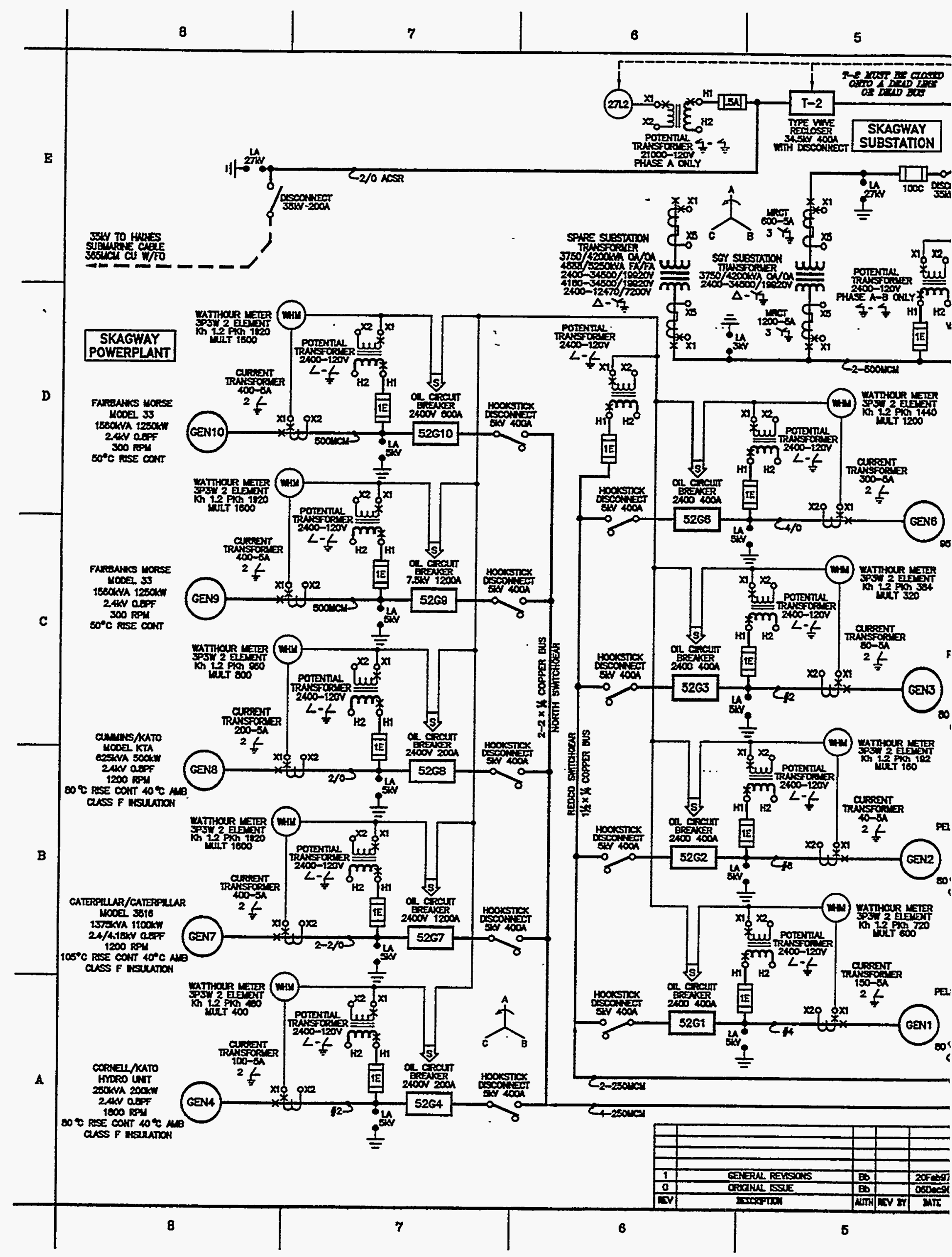




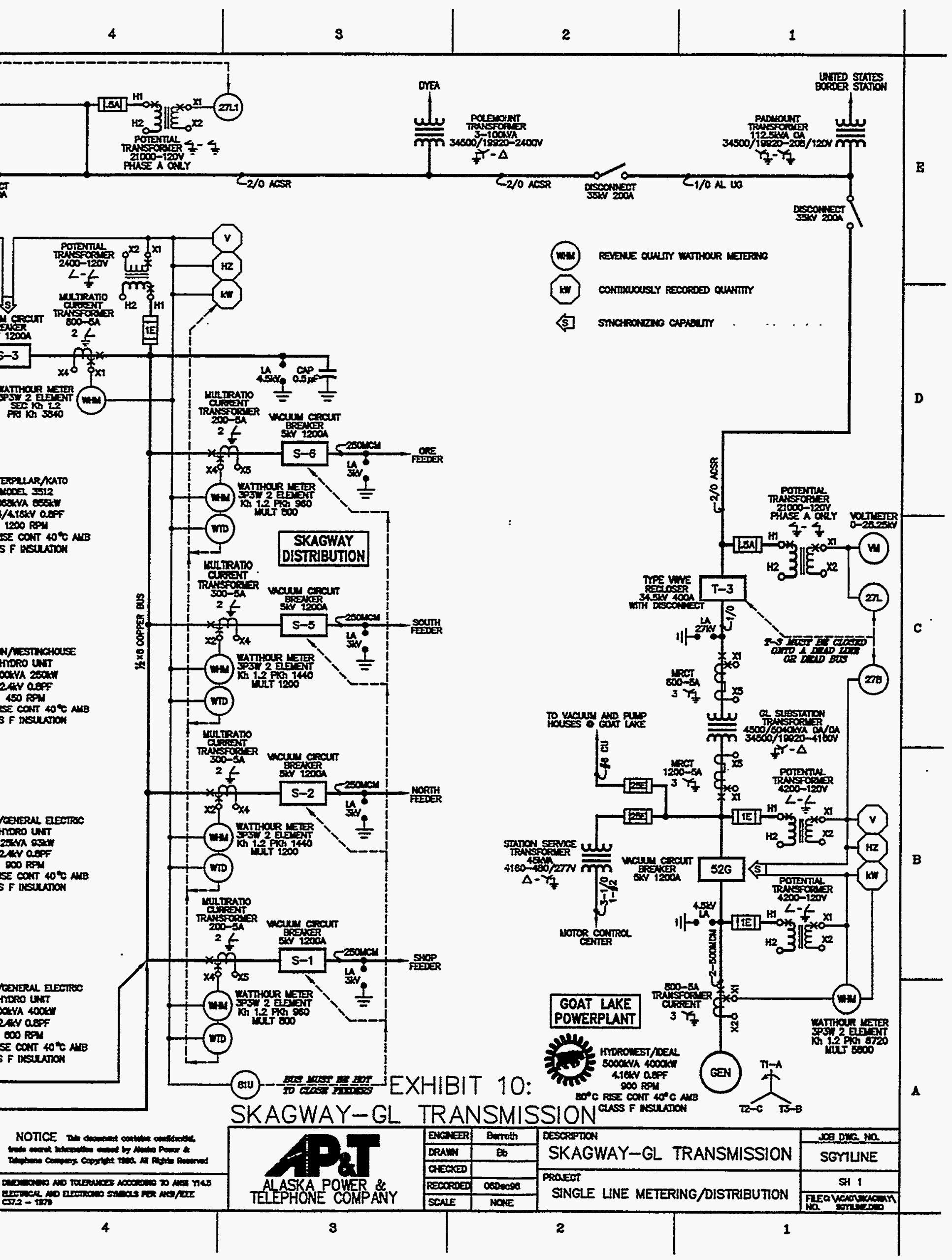




\section{HAINES - SKAGWAY \\ SUBMARINE CABLE INSTALLATION \\ TECHNICAL REPORT}

APPENDIX C

PROJECT PHOTOGRAPHS

(PHOTOGRAPHS SHOWING ALL PHASES OF PROJECT) 


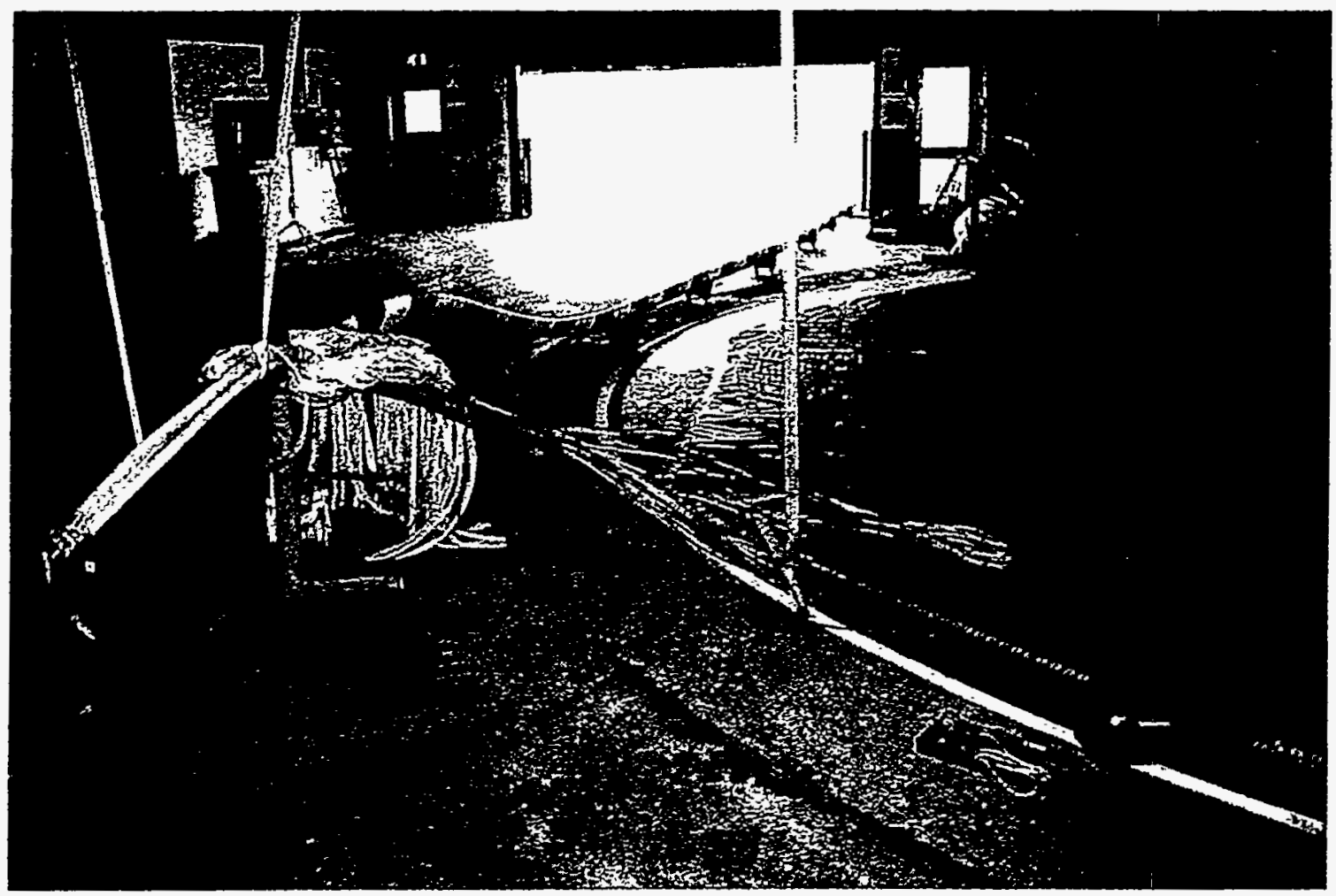

TESTING CABLE IN ENGLAND.

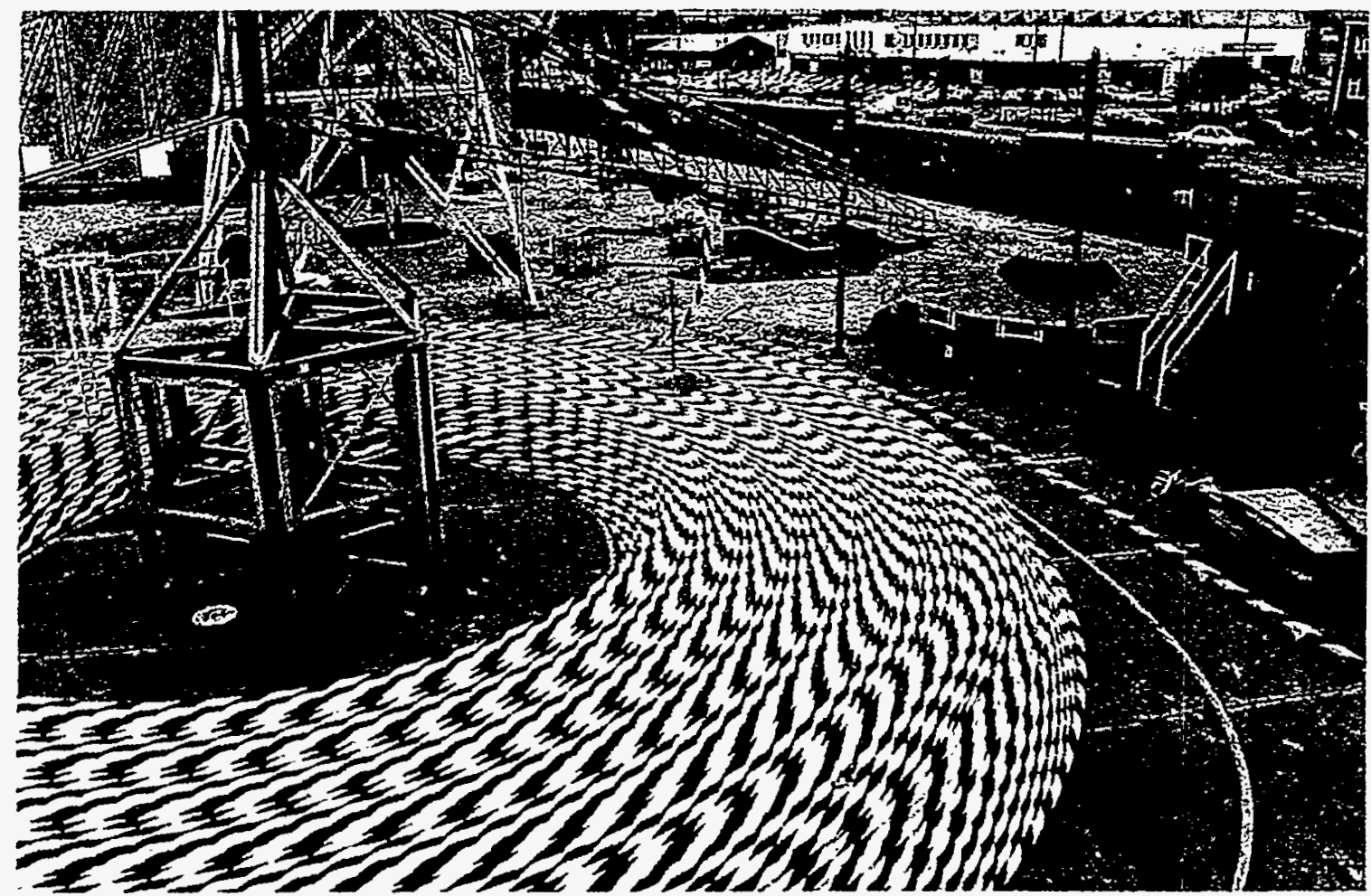

CABLE BEING PREPARED TO STORE IN ENGLAND UNTIL READY TO LOAD ONTO SHIP.

p. 1 


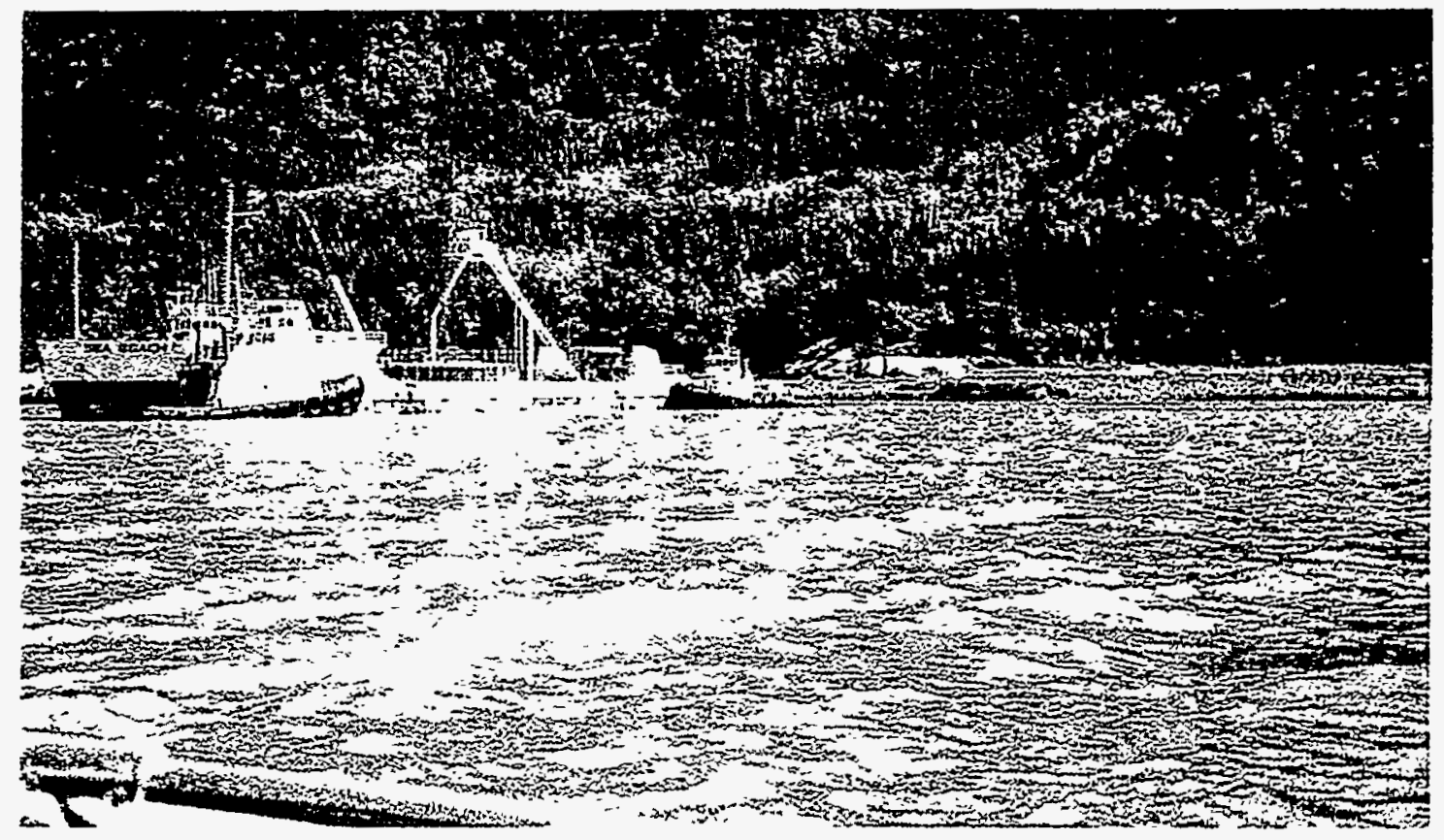

JUNE 27, 1998: CABLE LAYING SHIP "SEA BEACH" AT THE OTTER CREEK PROJECT SITE PREPARING TO LAY CABLE.

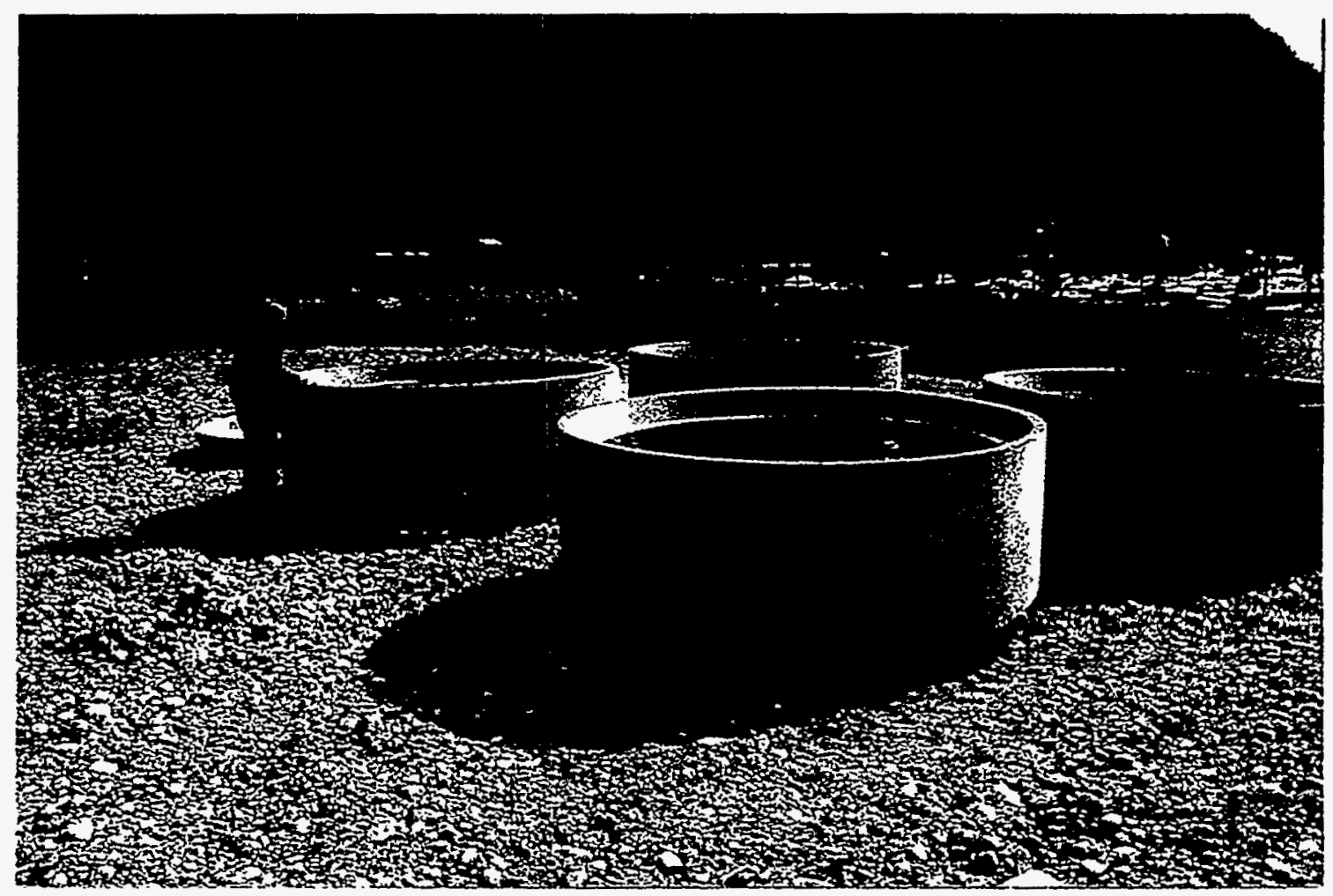

SPLICE VAULTS PRIOR TO TRANSPORTING TO THE VARIOUS

CABLE LANDING SITES. TWO OF THE CONCRETE STRUCTURES WERE REQUIRED FOR EACH VAULT. 


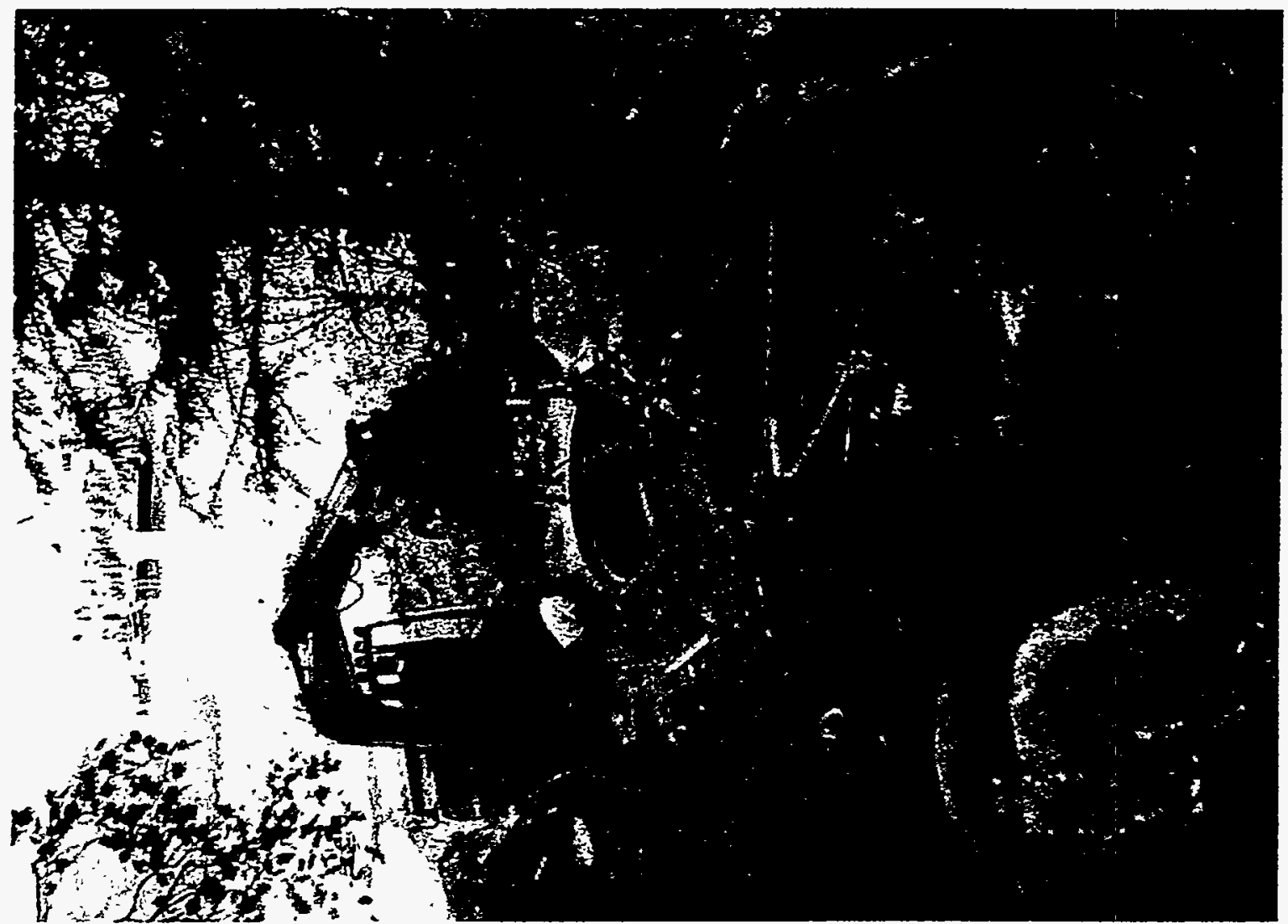

CABLE LAYING SHIP AT THE OTTER CREEK PROJECT SITE PREPARING TO LAY CABLE. SPLICE VAULT IS IN FOREGROUND. NOTE CABLE COMING OUT OF VAULT.

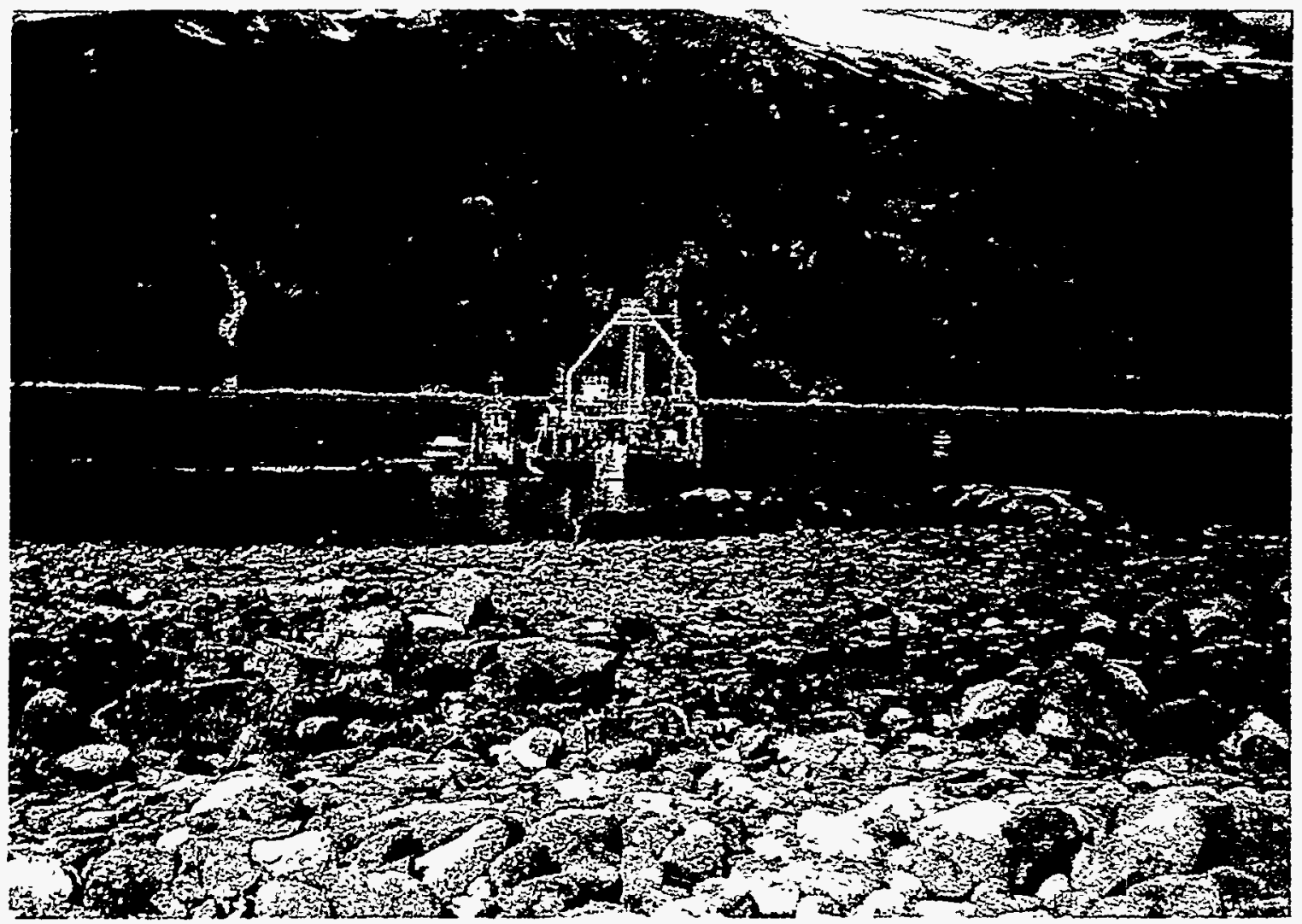
CABLE LAYING SHIP AT THE OTTER CREEK PROJECT SITE ON THE TAIYA INLET.

p. 3 

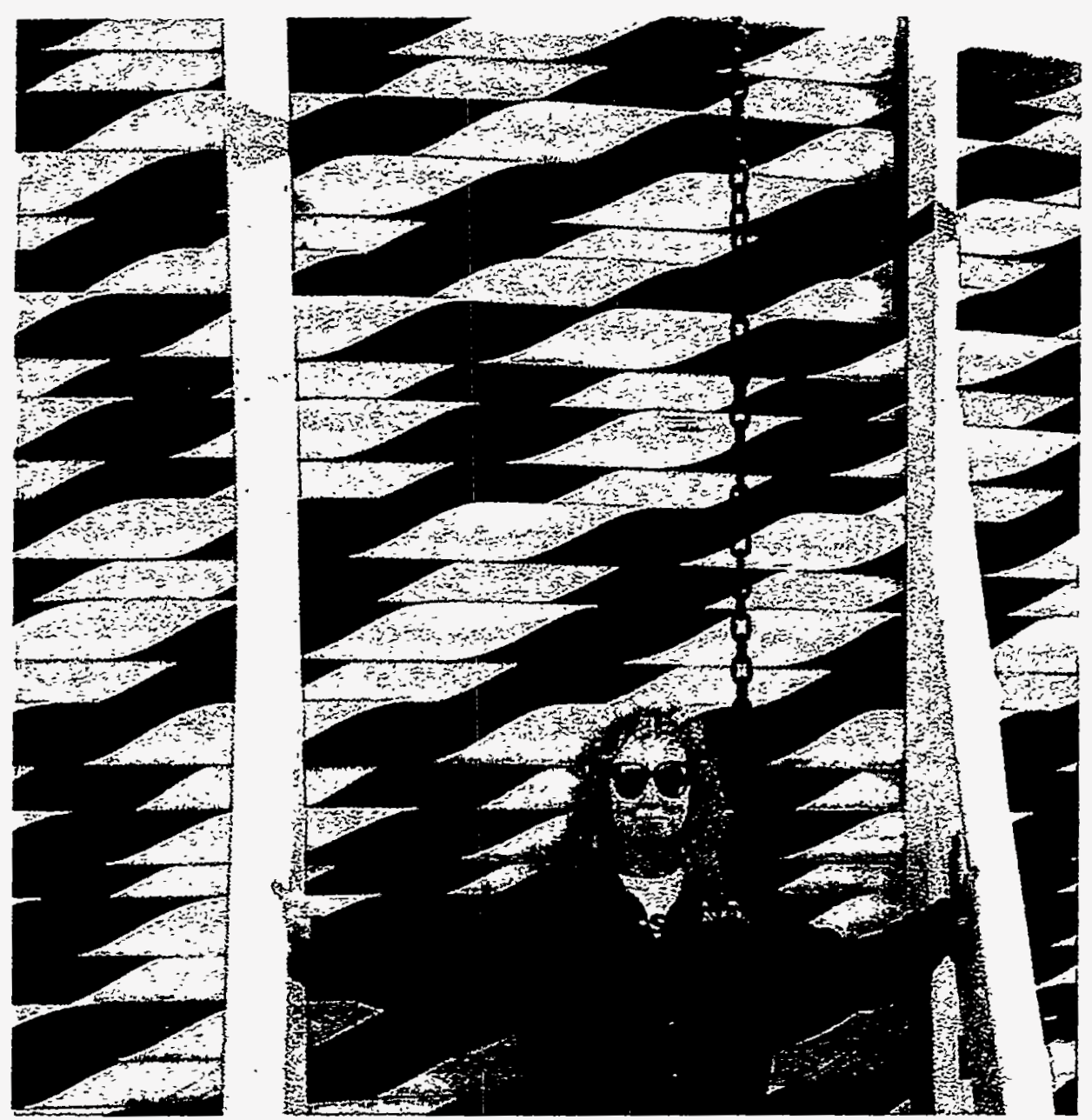

AN EXAMPLE OF THE SIZE OF THE CABLE.

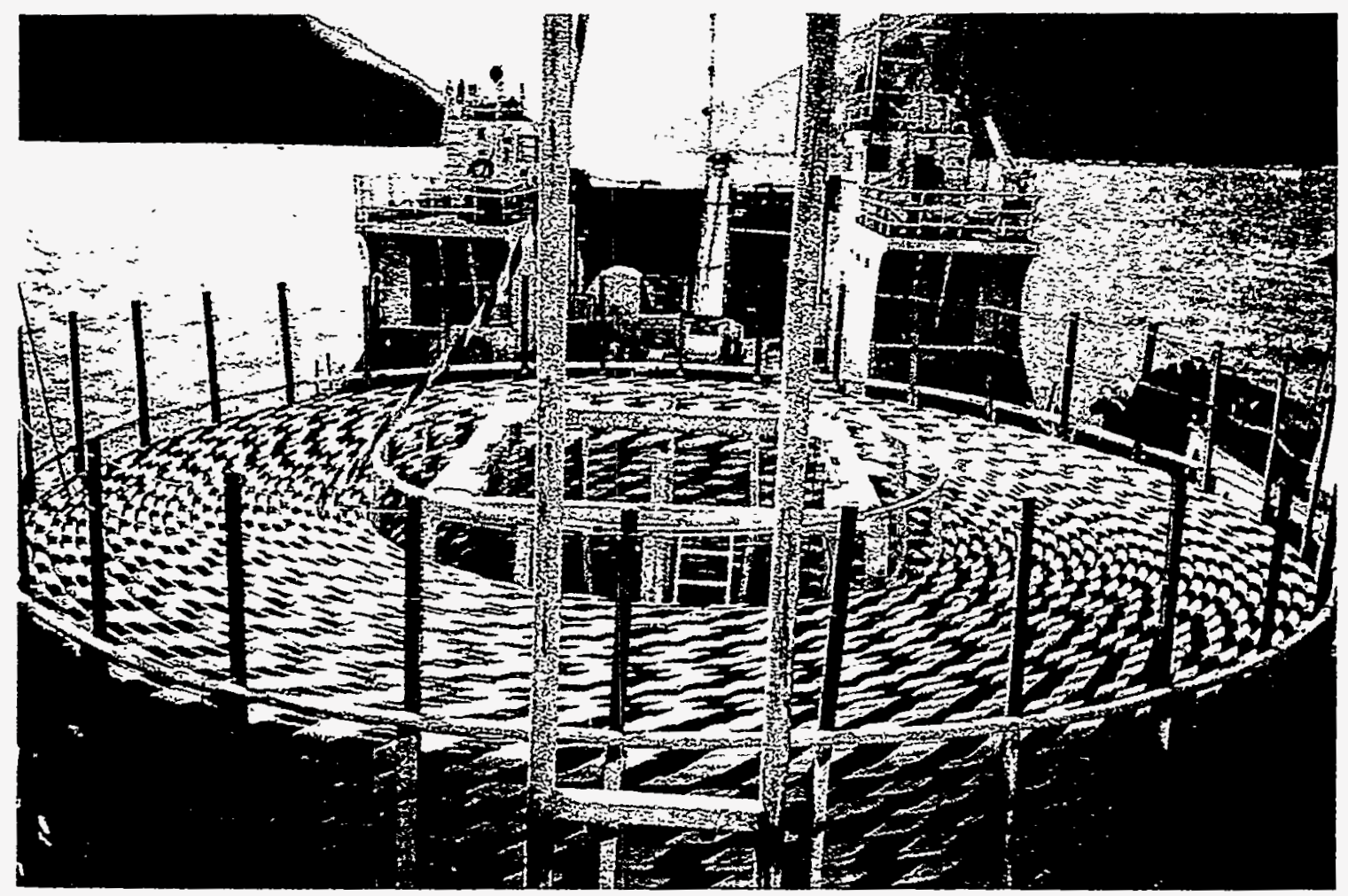

CABLE SPOOLED ON THE SHIP AS IT LAYS THE CABLE ALONG TAIYA INLET.

p. 4 


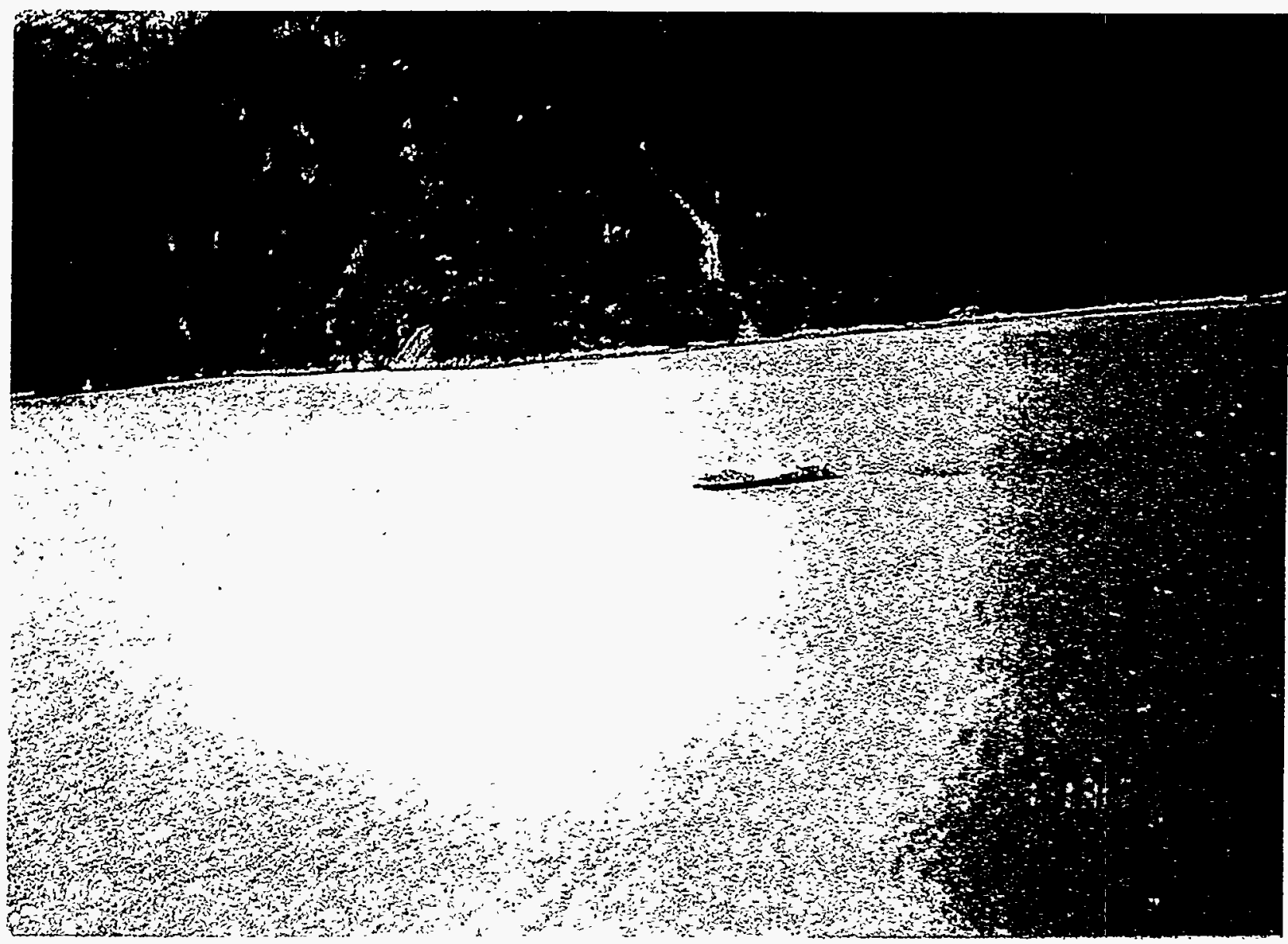

THE CABLE LAYING SHIP "SEA BEACH" HEADING TO HAINES AS IT LAYS THE CABLE IN TAIYA INLET.

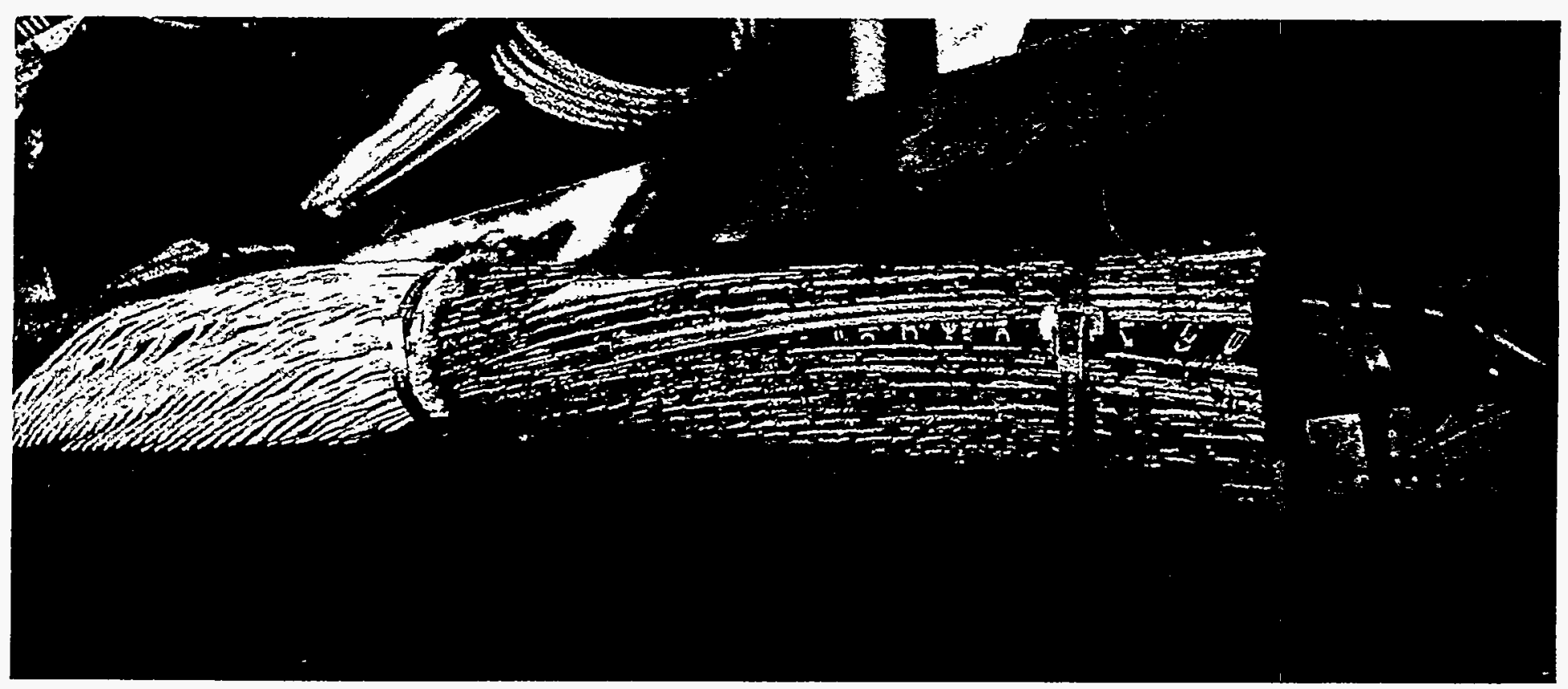

A CLOSEUP OF THE SUBMARINE CABLE.

p. 5 


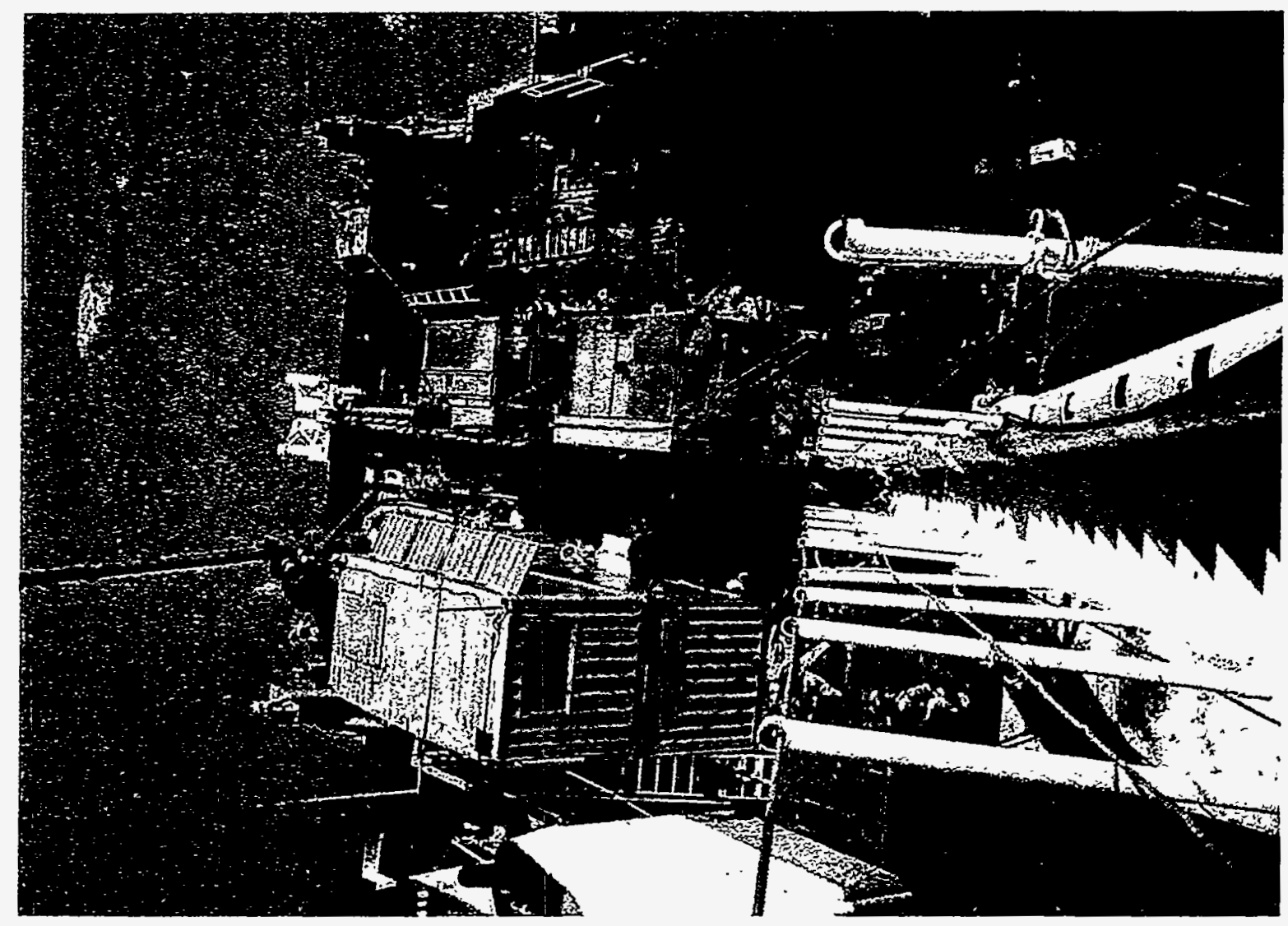

STERN VIEW OF CABLE LAYING SHIP WITH THE COMMAND STATION FOR MONITORING THE EQUIPMENT AND THE CABLE LOCATION AS IT IS LAID.

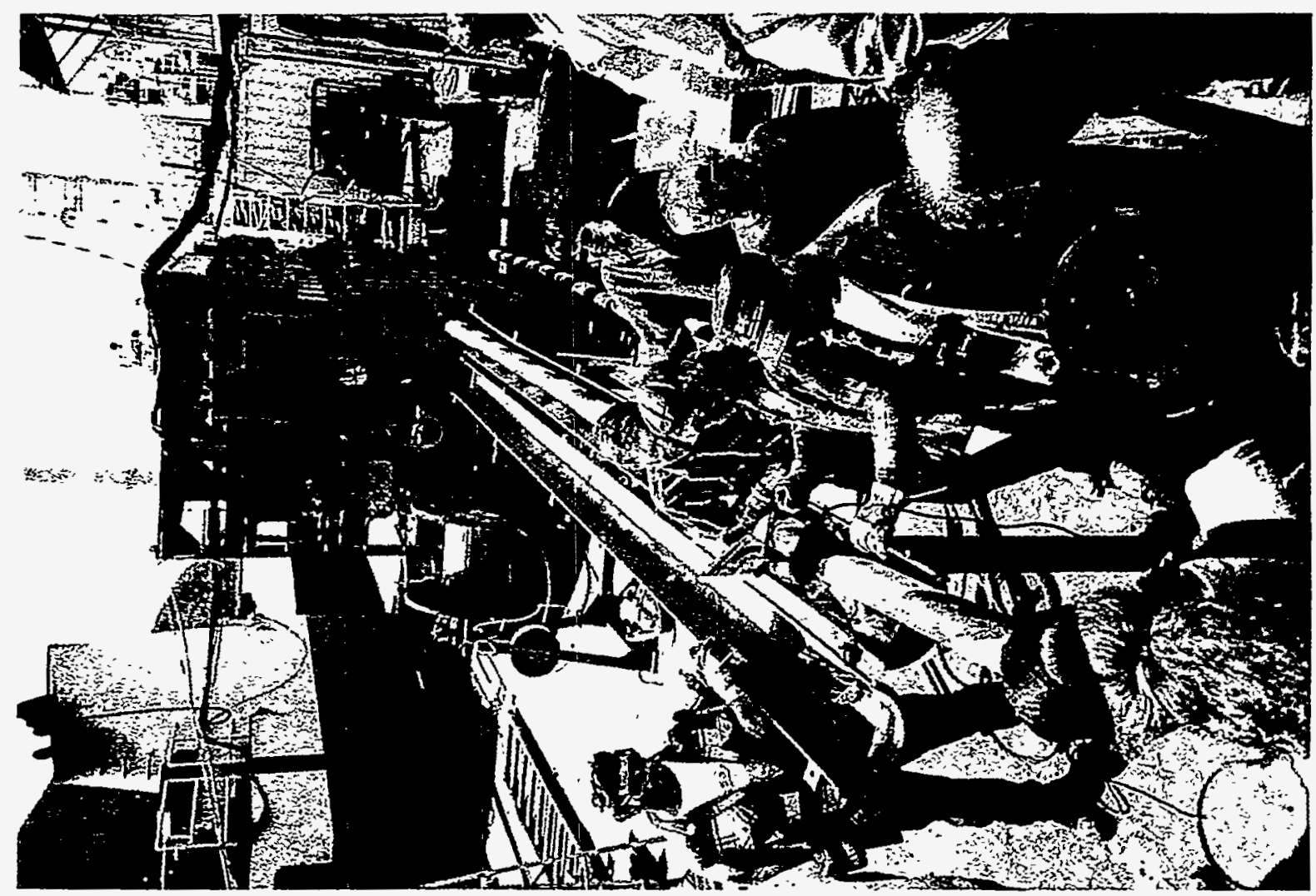

FROM STERN OF THE CABLE LAYING SHIP, PERSONNEL EXAMINE THE CABLE. 


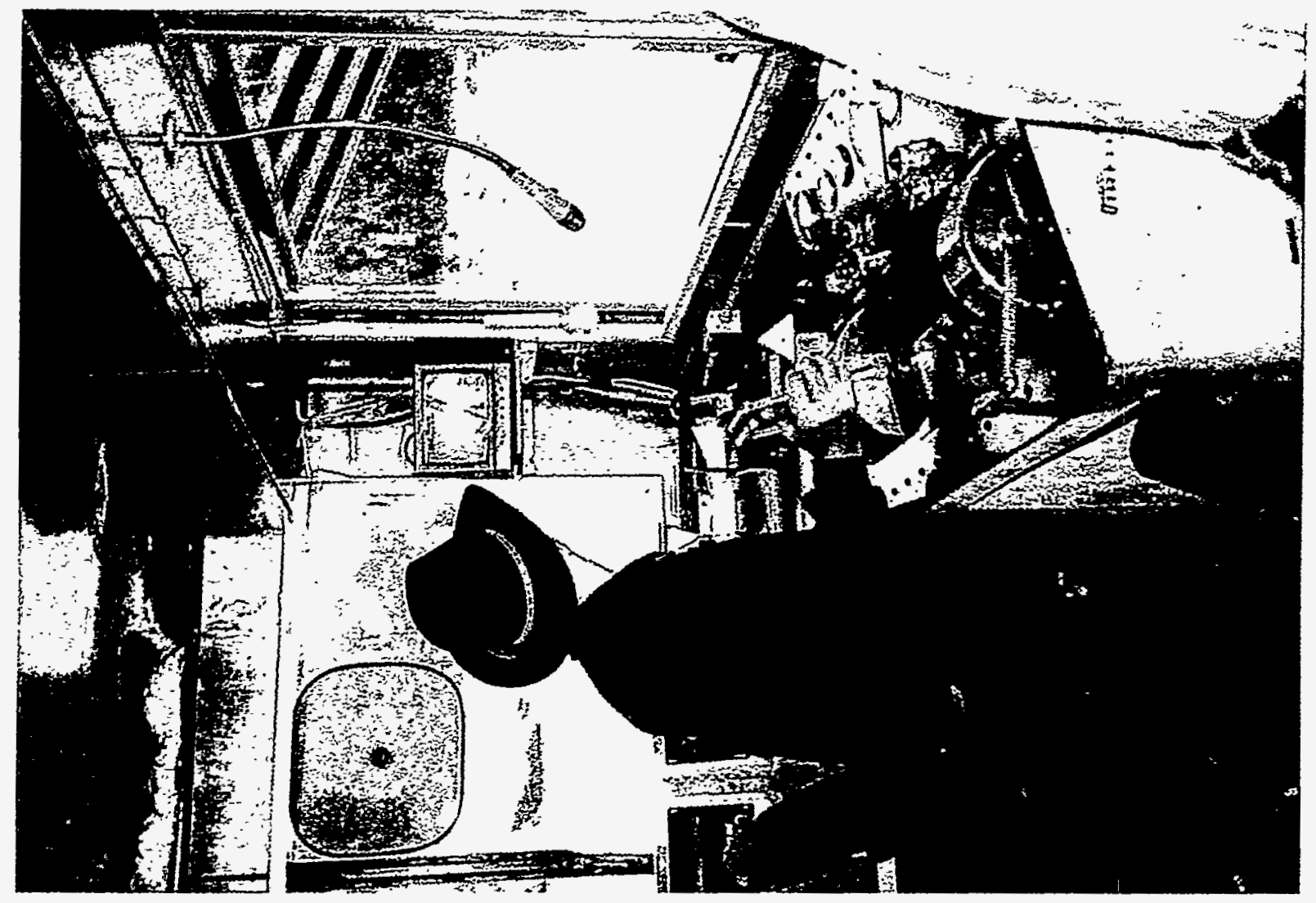

COMMAND STATION FOR CONTROL OF THE CABLE LAYING OPERATION.

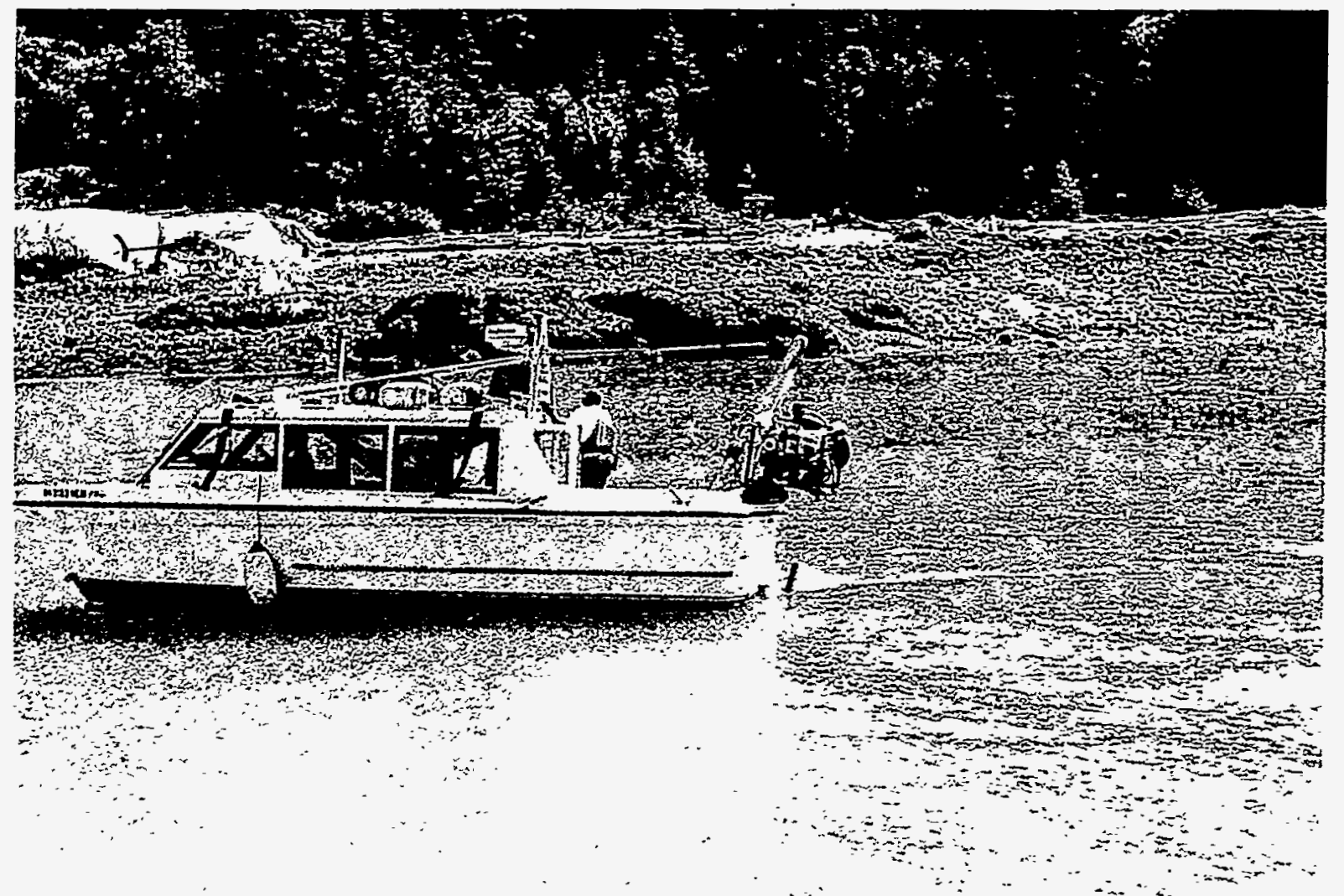

REMOTE SUBMERSIBLE ON BACK OF BOAT USED TO MONITOR THE LOCATION AND CONDITION OF THE CABLE AS IT IS LAID.

p. 7 


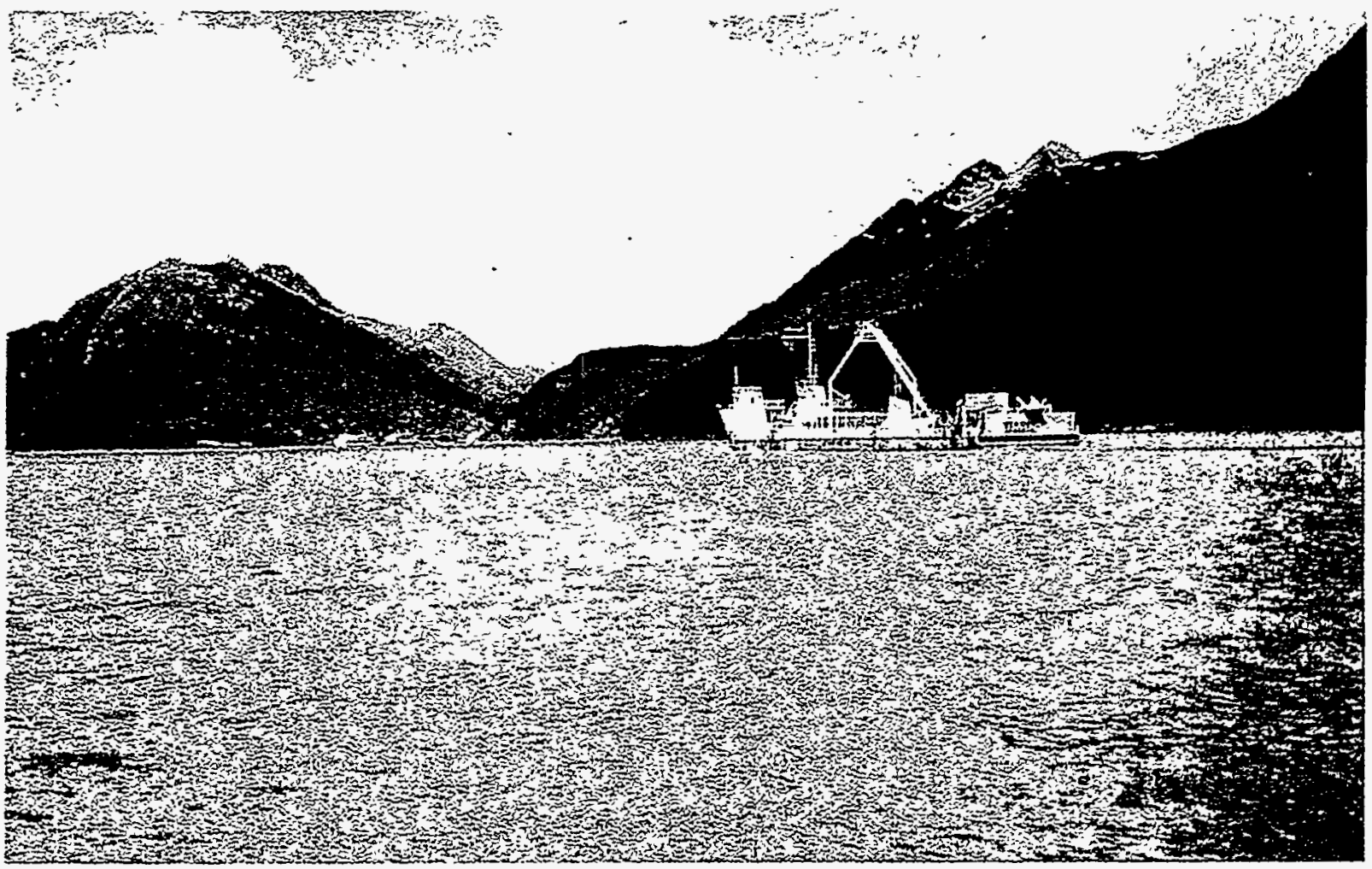

THE CABLE LAYING SHIP "SEA BEACH" HEADING TOWARDS SKAGWAY IN THE DISTANCE AS IT LAYS THE CABLE FROM THE OTTER CREEK PROJECT SITE.

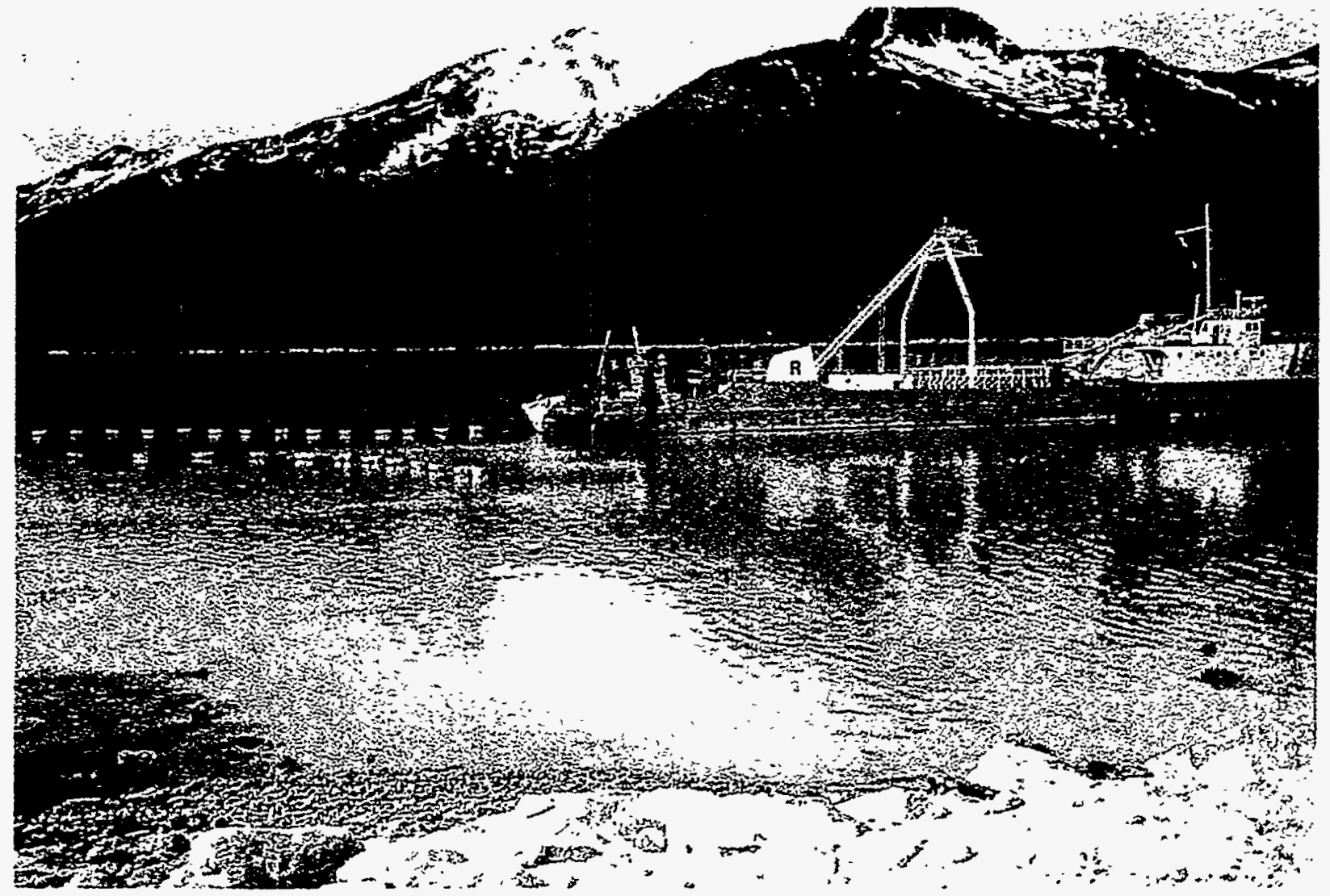

THE CABLE LAYING SHIP "SEA BEACH" AT THE SKAGWAY CABLE LANDING SITE, JUNE 30, 1998.

p. 8 


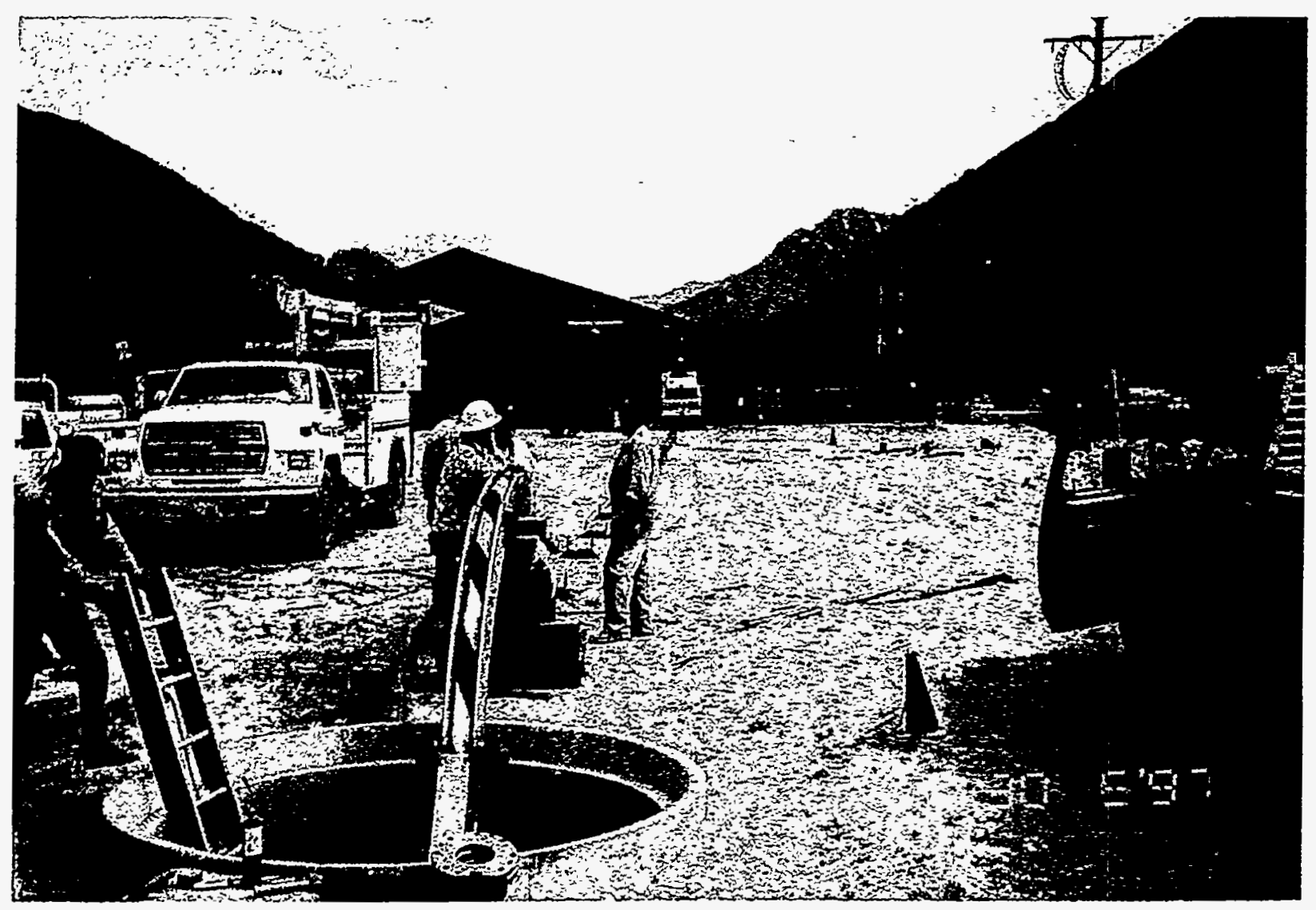

SKAGWAY CABLE LANDING; CABLE SHOWN PULLED THROUGH TO CONNECT WITH TRANSMISSION LINE.

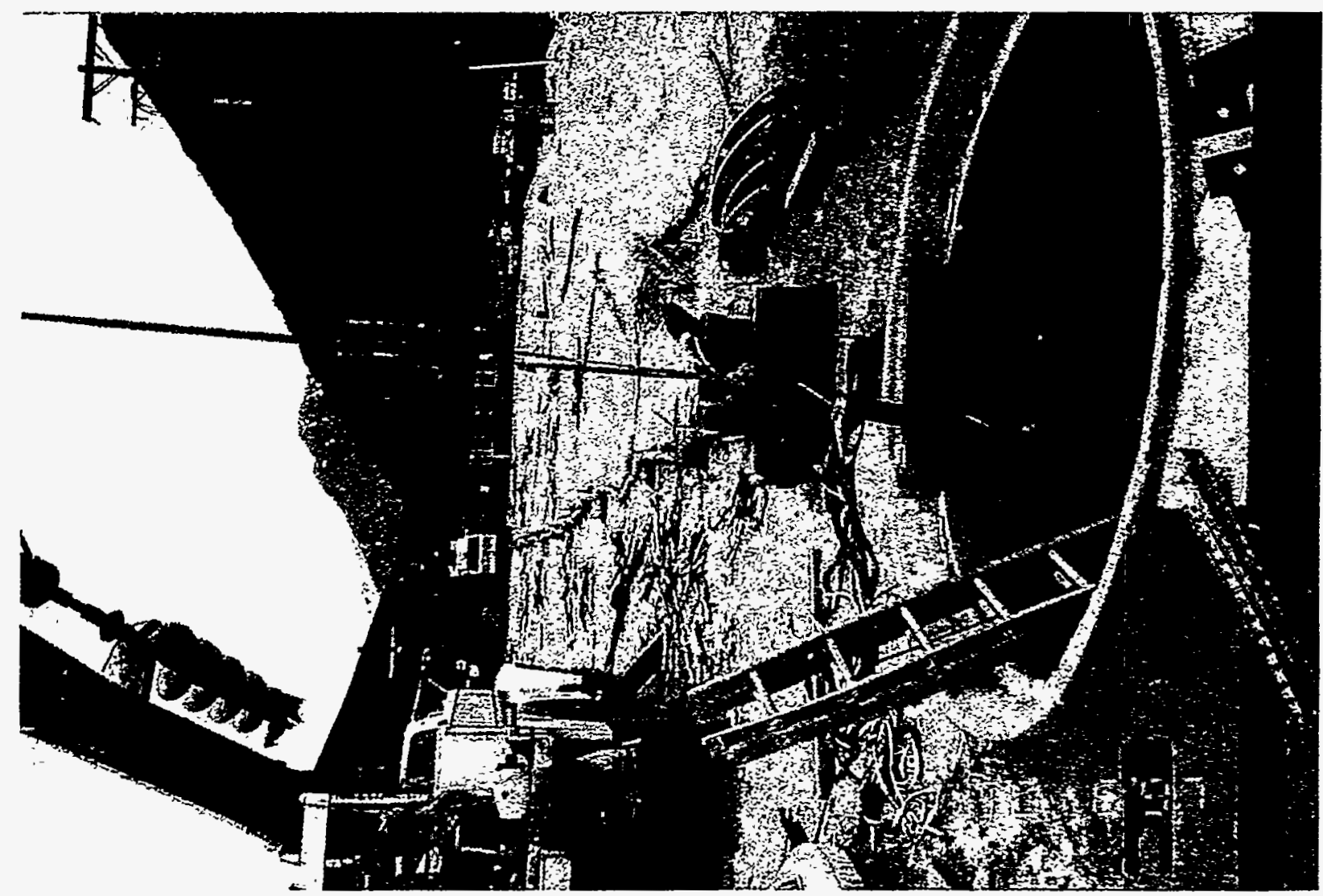

SKAGWAY CABLE LANDING; CABLE SHOWN STRIPPED OF ITS OUTER ARMOUR.

p. 9 


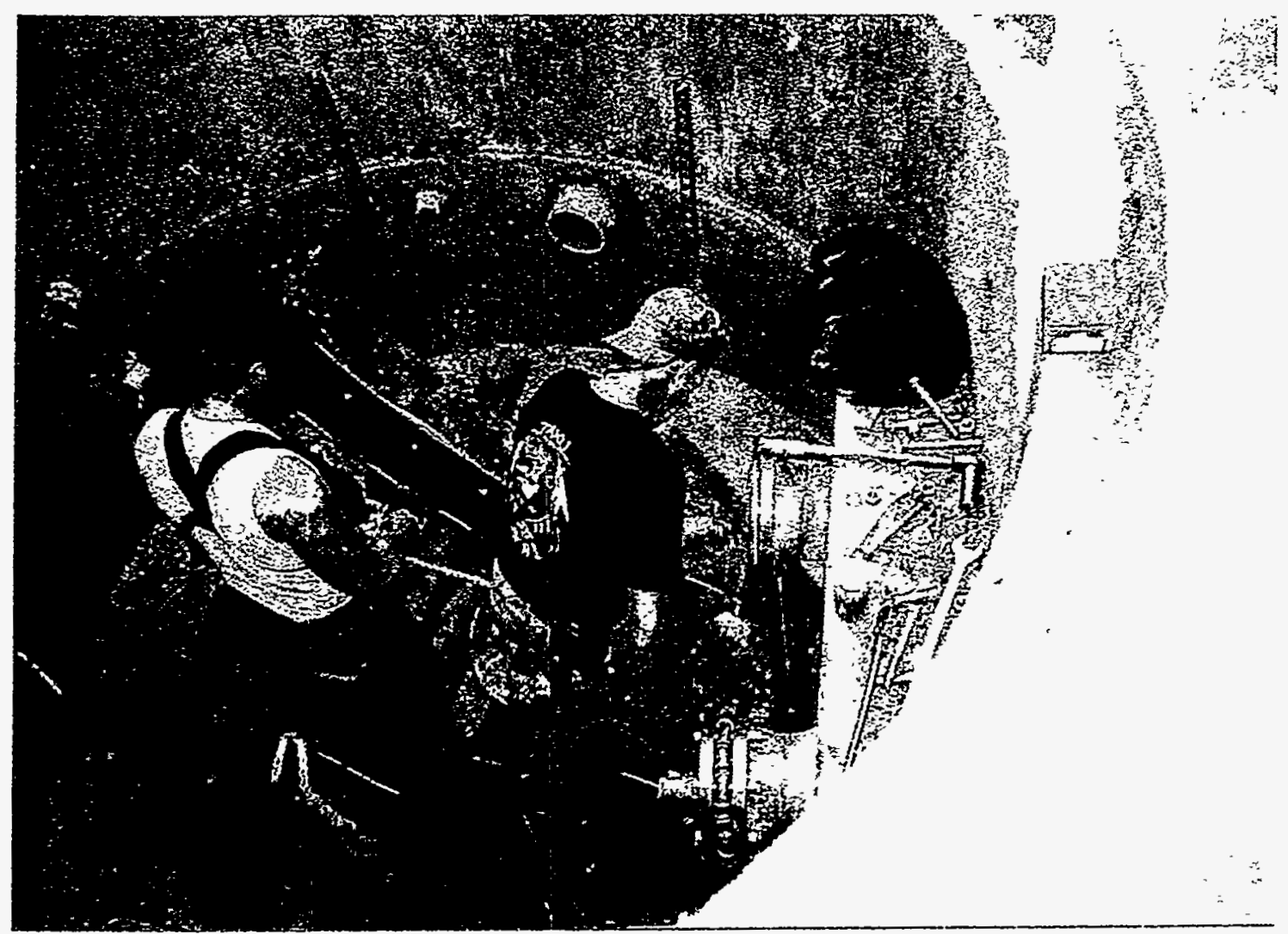

OTTER CREEK PROJECT CABLE LANDING; CABLE IS BEING ANCHORED TO REINFORCED VAULT.

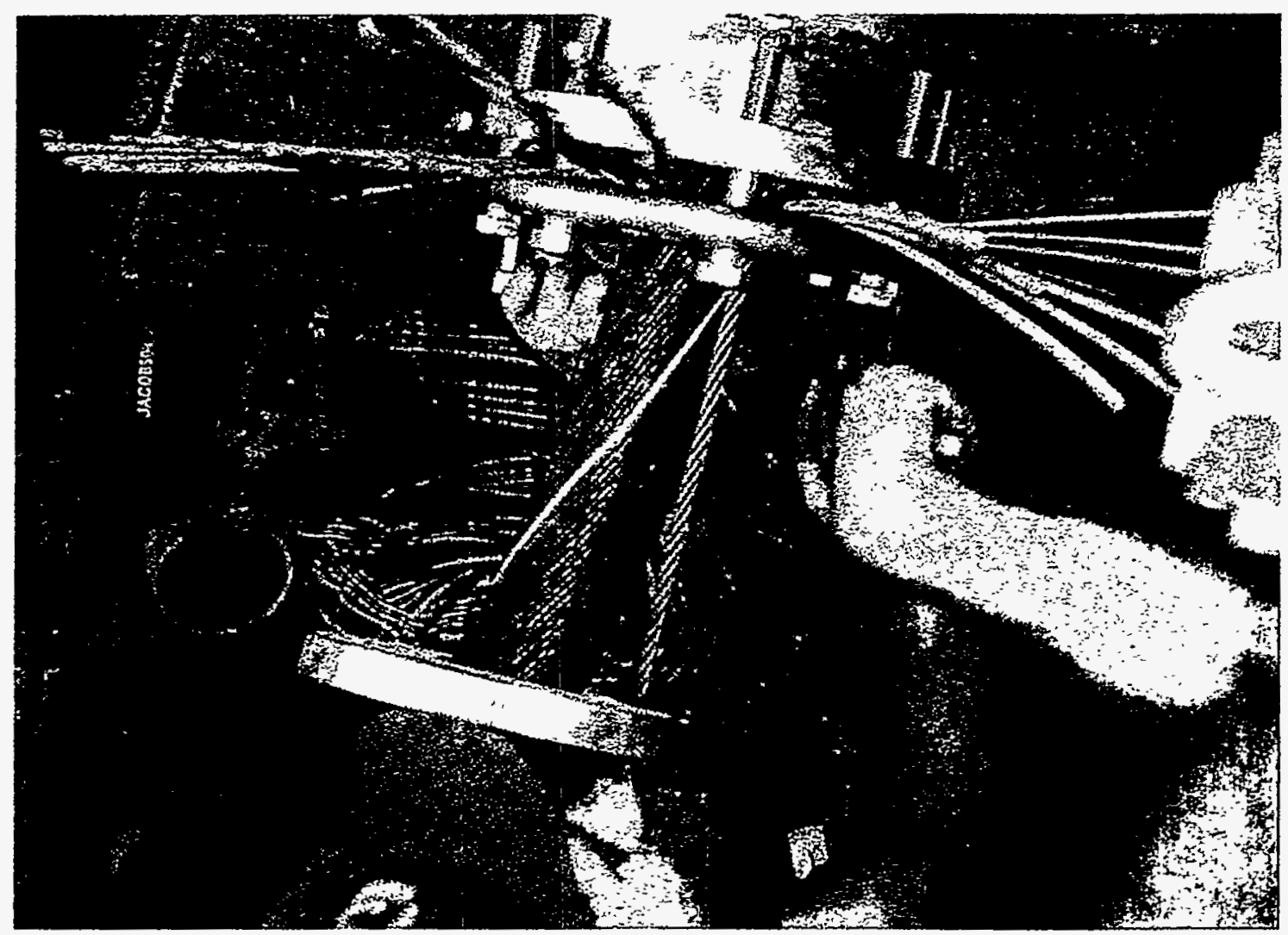

OTTER CREEK PROJECT CABLE LANDING; CABLE IS BEING ANCHORED TO REINFORCED VAULT.

p. 10 


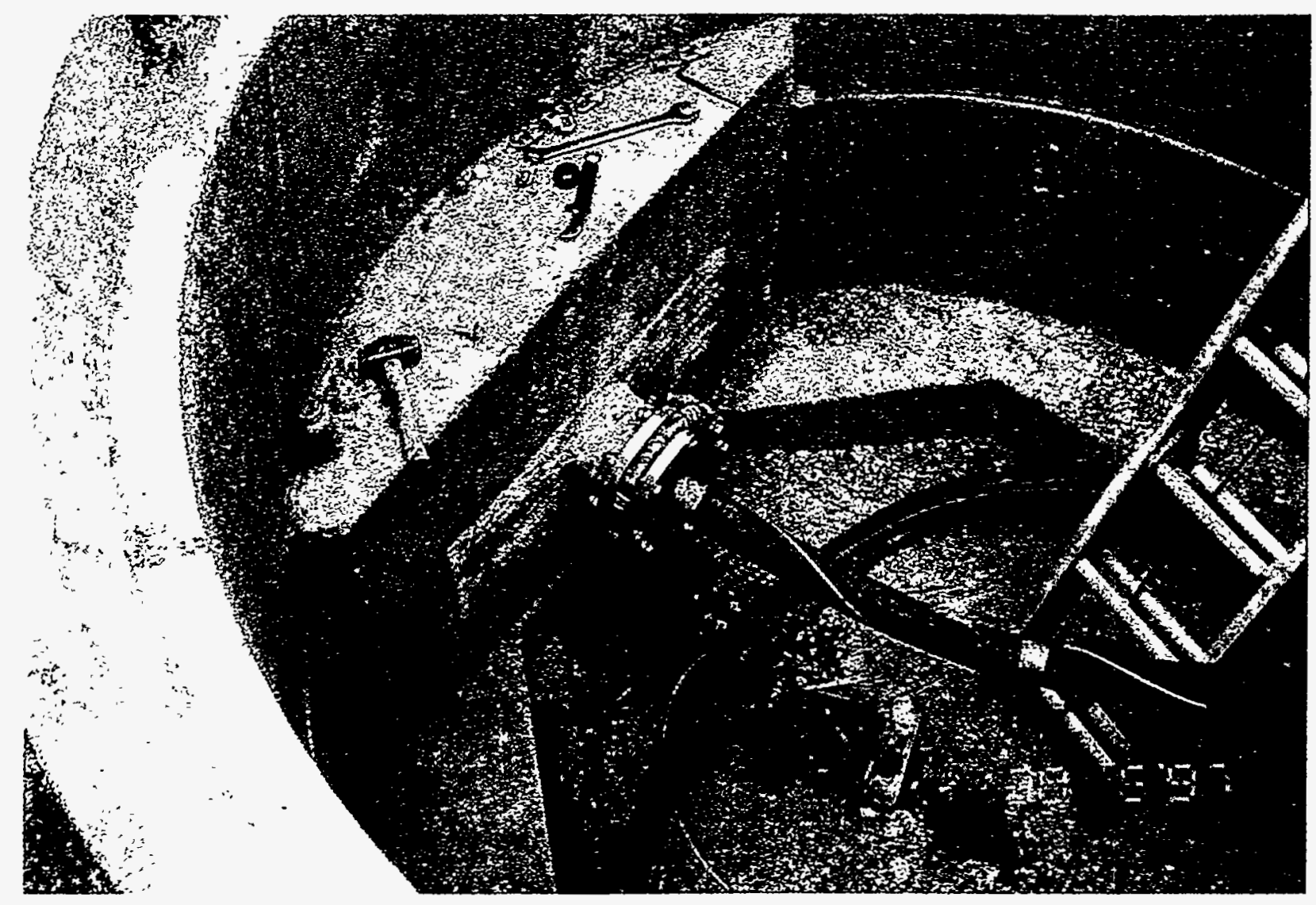

TYPICAL CABLE SPLICE VAULT AT HAINES AND SKAGWAY LANDINGS.

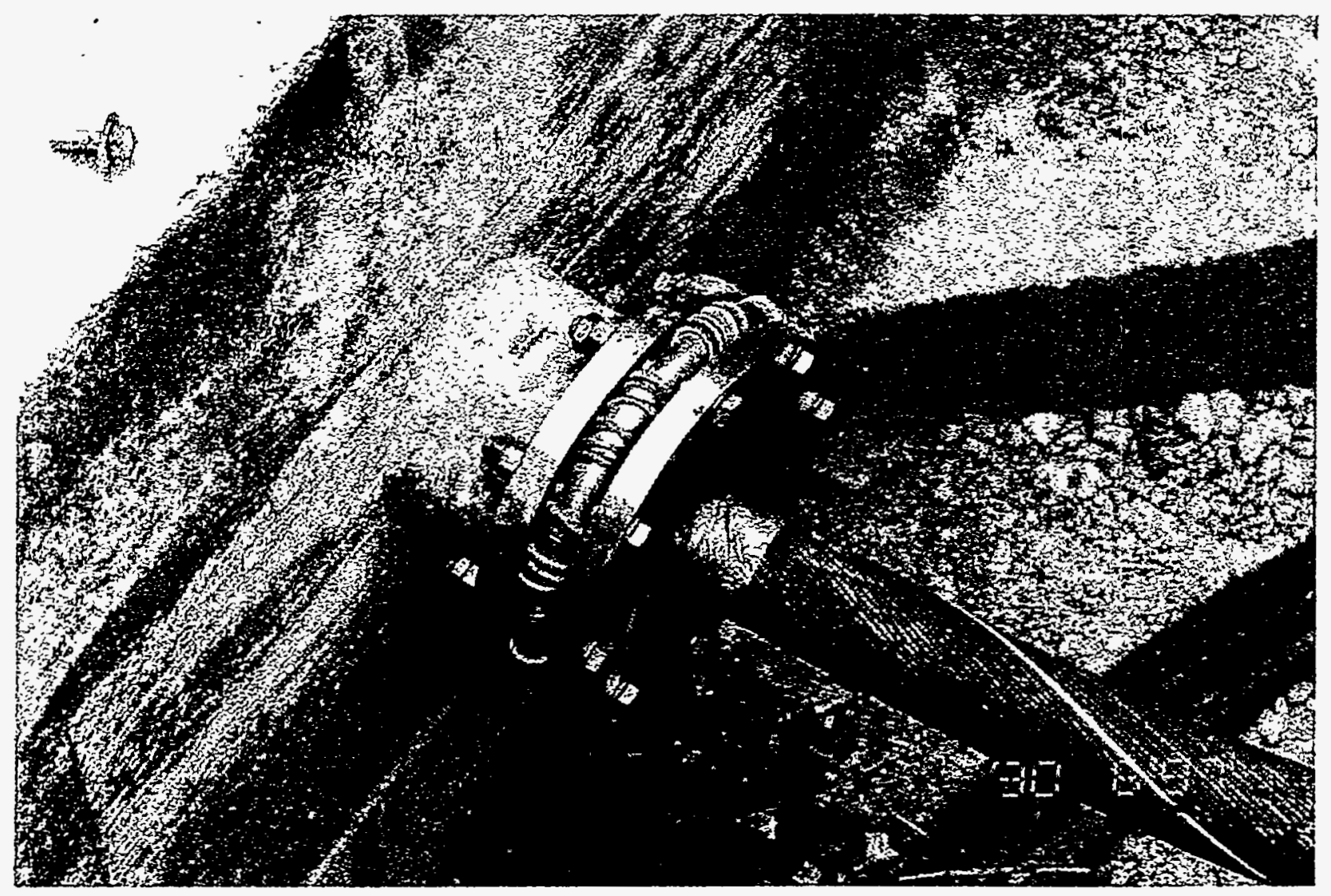

DETAIL OF CABLE SPLICE VAULT ANCHORING.

p. 11 